No $2013-09$

February

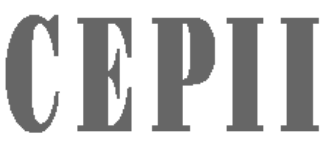

CENT TE

D.RTUDES ROSTECTIVER

ET D'INFORMATIONS

INTEENATIONALES

The Ability of Banks to Shift Corporate Income Taxes to Customers

Gunther CAPELLE-BLANCARD

Olena HAVRYLCHYK 


\section{TABLE OF CONTENTS}

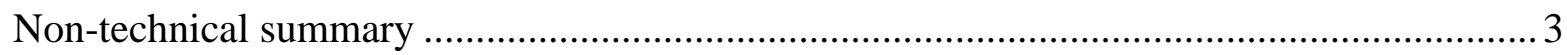

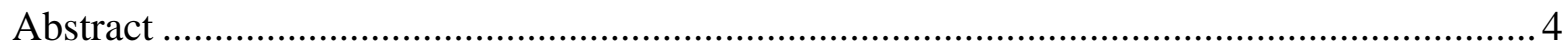

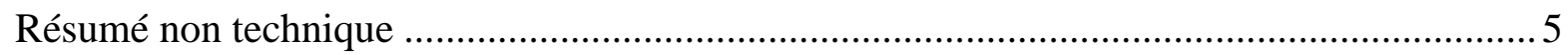

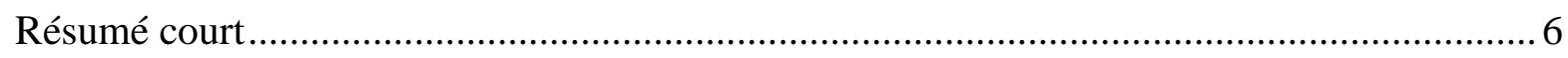

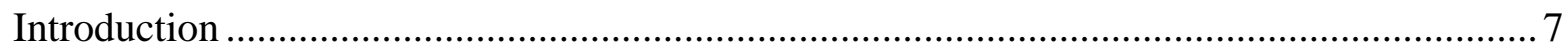

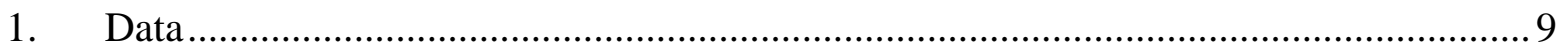

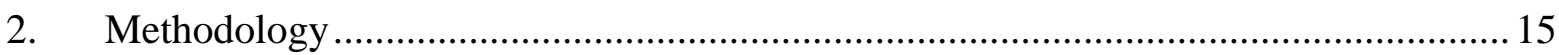

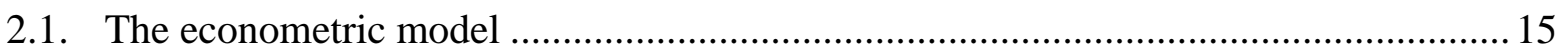

2.2. The source of heterogeneity: market power and competition.................................... 16

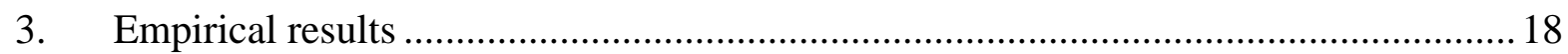

3.1. The impact of taxation on nominal interest margins .............................................. 18

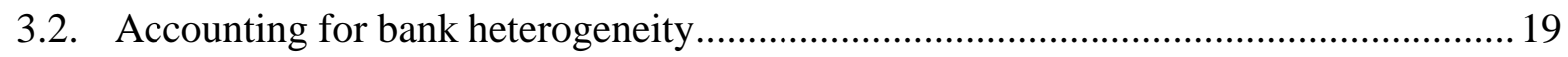

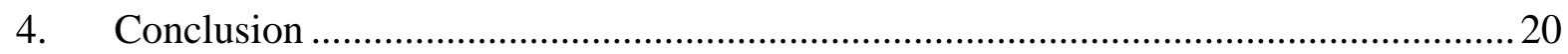

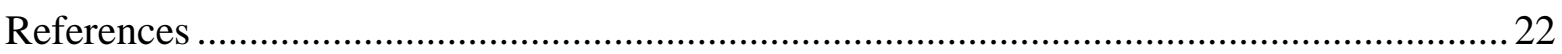

Appendix A. Variable description and descriptive statistics...............................................28

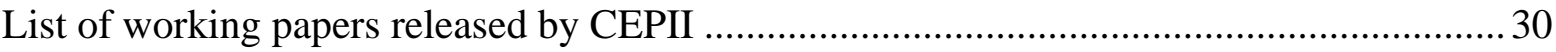




\title{
THE ABILITY OF BANKS TO SHIFT CORPORATE INCOME TAXES TO CUSTOMERS
}

\author{
Gunther Capelle-Blancard
}

Olena Havrylchyk

\section{NON-TECHNICAL SUMMARY}

The recent financial crisis has given rise to intense discussions about the costs and merits of bank taxation. Some proponents argue that its purpose should be recovering the costs of the direct fiscal support to banks or building up a reserve fund to ensure that taxpayers' money will not used for banks' bailouts in the future. Others claim that a bank levy could be designed as a Pigouvian tax that would serve as a macro-prudential tool to discourage banks from undertaking risky activities. Another motivation behind the current tax proposals is related to possible economic rents enjoyed by banks and, hence, a bank tax is sometimes presented as a tax to curb the growth of the financial industry. Finally, one can simply consider that an additional bank levy will offset a tax distortion due to the fact that financial services are exempted of VAT. In light of this debate, several EU countries (Austria, France, Germany, Hungary, Sweden, the UK, etc.) have introduced fees and taxes that vary according to their base and purpose.

Irrespective of the tax purpose, one of the most important questions is the tax incidence: who bears the effective burden? Imposing a tax on banks does not mean that banks will ultimately pay because, a priori, banks could pass on the burden of taxes to their customers by raising interest rates on loans and lowering interest rates on deposits, hence, increasing the cost of intermediation. As it was not possible to examine the impact of specific bank's taxes, several studies have examined the incidence of existing corporate income taxes. Overall, they find that a large part of corporate income taxes is passed on to customers. However, this conclusion is somewhat surprising since corporate income taxes - unlike sales tax - do not affect the maximization function of the firms and, consequently, should not be passed on.

In our study, we revisit the earlier empirical evidence on the pass-through of the corporate income tax burden. We argue that previous studies suffer either from the endogeneity problem due to omitted variable or from erroneous specification of the tax burden variable. We rely on 
a dataset of 1,411 European commercial banks over the period 1992-2008. Contrary to earlier studies, we find no evidence that banks shift corporate income taxes to their customers by widening the spread between lending and deposit rates. Importantly, we are able to replicate previous results by relying on their methodology; hence, our results are not driven by a different sample, but by a different methodology. We also test the robustness of our results by considering the level of market competition and banks' market power and find that our findings hold even for uncompetitive markets. The lack of tax incidence suggests that corporate income taxes are effectively born by the bank (shareholders or employees) and not by customers, in line with the theory.

\section{ABSTRACT}

In the context of the financial crisis, many projects of bank levies have emerged. Yet, there is very little evidence on the incidence of bank taxes and, hence, it is not clear who will bear the burden of the new taxes. In this paper, we investigate the ability of banks to shift corporate income taxes to their clients and we consider whether tax incidence is influenced by market competition and banks' market power. Our sample consists of 1,411 European commercial banks over the period 1992-2008. To measure competition we rely on a large number of indicators, such as banks' market share, the Herfindhal index, the Lerner index and the Panzar and Rosse h-statistic. We find that even in uncompetitive markets banks are not able to shift corporate income taxes to their customers. Our results contradict earlier papers that find a significant pass-through, and we argue that previous studies suffer either from endogeneity problems or from the wrong specification of the tax burden.

JEL Classification: G21, H25

Keywords: $\quad$ Bank taxation, Bank levy, Net interest margin, European banks, Banking market structure, Corporate tax incidence. 


\title{
LES BANQUES TRANSFERENT-ELLES A LEURS CLIENTS LEUR CHARGE FISCALE?
}

\author{
Gunther Capelle-Blancard \\ Olena Havrylchyk
}

\section{RÉSUMÉ NON TECHNIQUE}

En réaction à la crise récente et parallèlement aux initiatives règlementaires, on a vu fleurir de nombreux projets visant à un alourdissement de la fiscalité sur les activités bancaires. Ces projets diffèrent par leurs modalités (quel périmètre ? quelle assiette ? quel taux ?) et par leurs objectifs. Il s'agit, selon les cas, de faire supporter aux banques le coût de leur sauvetage, d'alimenter un fonds de garantie évitant à l'avenir aux contribuables d'avoir à renflouer les banques en faillite, de décourager les comportements les plus risqués, de compenser certaines distorsions fiscales (les services financiers ne sont pas soumis à la TVA), de limiter la taille du secteur financier, voire, simplement, d'augmenter les recettes budgétaires mises à mal par la crise. Certaines initiatives ont déjà vu le jour, notamment en Europe, d'autres sont encore en discussion.

Indépendamment des modalités ou des objectifs d'une taxe sur les activités bancaires, une question cruciale se pose. Qui supporte in fine le fardeau fiscal : les banques ou leurs clients? Un des arguments avancés (par le FMI et par la Commission européenne notamment) pour justifier un alourdissement de la charge fiscale des banques est que celles-ci jouissent de rentes du fait des garanties implicites apportées par les Etats et d'un manque de concurrence sur certains segments de marché. Cependant, imposer une taxe sur les banques ne garantit pas que ce soit elles qui en supportent le coût ; elles peuvent le transmettre à leurs clients en augmentant le coût de l'intermédiation - autrement dit, en augmentant les taux d'intérêt sur les prêts ou en diminuant celui sur les dépôts.

Dans cette étude, nous examinons empiriquement la capacité des banques à transmettre la charge fiscale à leurs clients. Bien qu'essentielle, cette question n’a pas reçu jusque-là beaucoup d'attention. Quelques études empiriques ont montré que les banques répercutaient sur leurs clients une partie de l'impôt sur les sociétés qui leur incombait, mais ces études souffrent de nombreux problèmes méthodologiques (endogénéité, variable omise, mauvaise 
spécification de la charge fiscale) et aucune ne tient compte du pouvoir de marché des banques, ni du degré de concurrence. Par ailleurs, leur résultat est surprenant dans la mesure où l'imposition des revenus - contrairement aux taxes sur les produits - n'affecte pas la stratégie de la firme et ne devrait donc pas avoir d’incidence.

Notre base de données regroupe 1411 banques commerciales européennes sur la période 1992-2008. Nos résultats suggèrent que les banques ne transfèrent pas l'impôt sur les sociétés à leurs clients : nous ne trouvons pas de lien significatif entre leur taux d'imposition implicite (calculé en rapportant l'impôt sur les sociétés au résultat avant impôt) et la marge d'intérêt. Ce résultat est en contradiction avec les études antérieures et nous vérifions que ce désaccord n'est pas lié à des différences d'échantillonnage mais bien à la façon dont nous traitons plusieurs problèmes méthodologiques des estimations précédentes. En outre, nous trouvons que l'incidence fiscale n'est guère sensible au degré de concurrence ni au pouvoir de marché des banques ; nos conclusions restent donc valables pour des marchés peu concurrentiels.

\section{RÉSUMÉ COURT}

Dans cet article nous examinons empiriquement dans quelle mesure les banques transmettent à leurs clients la charge de la taxation de leur revenu. Notre échantillon est composé de 1411 banques européennes sur les années 1992 à 2008. Il en ressort que l'incidence fiscale est faible, voire nulle. Ce résultat contredit les études antérieures dont nous montrons qu'elles souffrent de sérieux problèmes méthodologiques (endogénéité, variable omise, mauvaise spécification de la charge fiscale).

Classification JEL : G21, H25

Mots-clefs : $\quad$ Taxe bancaire, marge d'intérêt, secteur bancaire européen, incidence fiscale. 


\title{
THE ABILITY OF BANKS TO SHIFT CORPORATE INCOME TAXES TO CUSTOMERS ${ }^{\diamond}$
}

\author{
Gunther CAPELLE-BLANCARD* \\ Olena HAVRYLCHYK ${ }^{\Upsilon}$
}

\section{INTRODUCTION}

The recent financial crisis has given rise to intense discussions about the costs and merits of bank taxation. Some proponents argue that its purpose should be recovering the costs of the direct fiscal support to banks or building up a reserve fund to ensure that taxpayers' money will not used for banks' bailouts in the future. Others claim that a bank levy could be designed as a Pigouvian tax that would serve as a macro-prudential tool to discourage banks from undertaking risky activities. Another motivation behind the current tax proposals is related to possible economic rents enjoyed by banks and, hence, a bank tax is sometimes presented as a tax to curb the growth of the financial industry (International Monetary Fund, 2010; European Commission, 2010). Finally, we can simply consider that an additional bank levy will offset a tax distortion due to the fact that financial services are exempted of VAT (Huizinga, 2002). In light of this debate, several European countries (Austria, France, Germany, Hungary, Sweden, the UK, etc.) have introduced fees and taxes that vary according to their base and purpose; for a comprehensive presentation, see (EC DG TAXUD, 2012a).

Irrespective of the tax purpose, one of the most important questions is the tax incidence: who bears the effective burden? Imposing a tax on banks does not mean that banks will ultimately pay because, a priori, banks could pass on the burden of the new taxes to their customers by raising interest rates on loans and lowering interest rates on deposits, hence, increasing the cost of intermediation.

\footnotetext{
The authors thank Agnès Bénassy-Quéré, Vincent Bouvatier, Jézabel Couppey-Soubeyran, Michael Devereux, Iftekhar Hasan, Stéphane Gauthier, Christa Hainz, Laetitia Lepetit, Ruud de Mooij, Gaetan Nicodeme, Alain Trannoy, and Christian Valenduc, as well as participants at CESifo Venice Summer Institute Conference on the Taxation of the Financial Sector (2012), the GdRE Symposium on Money, Banking and Finance (2012), the AFSE 61th Congress, the World Finance \& Banking Symposium (2012), and the Banque de France Seminar (2012) for helpful comments. They also thank Claire Labonne for research assistance.

* Cepii \& Université Paris 1 Panthéon-Sorbonne. E-mail: gunther.capelle-blancard@univ-paris1.fr.

${ }^{\Upsilon}$ Cepii. E-mail: olena.havrylchyk@cepii.fr. Corresponding author: 113 rue de Grenelle 75007 Paris, France. Phone: +33 (0)1 53685509 .
} 
Despite the importance of the tax incidence question, the empirical literature on the banking sector is rather scarce (see Table 1). As it was not possible to examine the impact of specific bank's taxes, a few studies analyze tax incidence of the existing corporate income taxes on different bank performance measures, most often on net interest margins (NIM). DemirgücKunt and Huizinga (1999, 2001) analyze bank level data for 80 countries (1988-1995) and find that a large part of bank taxes is passed on to banks' customers by increasing the spread between lending and deposit rate. In a more recent study, Huizinga et al. (2011) focus on international banks and find that double taxation is almost fully reflected in the interest margins charged by foreign subsidiary banks. Albertazzi and Gambacorta (2010) analyze country level data in the OECD for the period 1981-2003 and find that $90 \%$ of the corporate income tax is passed by banks to their customers by raising lending rates. A similarly high pass-through is found by Chiorazzo and Milani (2011) for a sample of the EU banks for the period 1990-2005. Thus, the literature, although relatively small, seems to have reached a consensus and as stated by the European Commission in its impact assessment, "overall, available studies suggest that financial companies are able to pass on taxes to their customers" (EC DG TAXUD, 2012b).

Table 1. Previous tax incidence studies applied to the banking sector

\begin{tabular}{|c|c|c|c|c|c|}
\hline Studies & Sample & Data & $\begin{array}{l}\text { Dependent } \\
\text { variables }\end{array}$ & $\begin{array}{c}\text { Variables of } \\
\text { interest }\end{array}$ & $\begin{array}{l}\text { Econometric } \\
\text { Method }\end{array}$ \\
\hline $\begin{array}{l}\text { Demirgüc-Kunt, \& } \\
\text { Huizinga (1999) }\end{array}$ & $\begin{array}{l}80 \text { countries } \\
(1988-95)\end{array}$ & $\begin{array}{c}\text { Bankscope } \\
\text { (5,841 banks) }\end{array}$ & $\begin{array}{l}\text { NIM, Pre-tax } \\
\text { profit }\end{array}$ & Implicit Tax Rate & $\begin{array}{l}\text { Cross-section, } \\
\text { weighted least } \\
\text { squares }\end{array}$ \\
\hline $\begin{array}{l}\text { Demirgüc-Kunt, \& } \\
\text { Huizinga (2001) }\end{array}$ & $\begin{array}{l}80 \text { countries } \\
(1988-95)\end{array}$ & $\begin{array}{c}\text { Bankscope } \\
(5,391 \text { banks })\end{array}$ & $\begin{array}{l}\text { NIM, Pre-tax } \\
\text { profit }\end{array}$ & $\begin{array}{c}\text { Average Implicit } \\
\text { Tax Rate, } \\
\text { Statutory Tax } \\
\text { Rate }\end{array}$ & $\begin{array}{l}\text { Cross-section, } \\
\text { OLS }\end{array}$ \\
\hline $\begin{array}{l}\text { Albertazzi \& } \\
\text { Gambacorta (2010) }\end{array}$ & $\begin{array}{l}10 \text { OECD } \\
\text { countries } \\
(1981-03)\end{array}$ & $\begin{array}{l}\text { OECD \& IMF } \\
\text { (macro data) }\end{array}$ & $\begin{array}{l}\text { NIM, Non- } \\
\text { interest income, } \\
\text { Provisions, Pre- } \\
\text { tax profit }\end{array}$ & $\begin{array}{l}\text { Statutory Tax } \\
\text { Rate }\end{array}$ & $\begin{array}{c}\text { Dynamic panel, } \\
\text { GMM }\end{array}$ \\
\hline $\begin{array}{l}\text { Huizinga et al. } \\
\text { (2011) }\end{array}$ & $\begin{array}{l}38 \text { countries } \\
(199 x-08)\end{array}$ & $\begin{array}{c}\text { Bankscope } \\
(9,729 \text { banks })\end{array}$ & $\begin{array}{l}\text { NIM, Pre-tax } \\
\text { profit }\end{array}$ & $\begin{array}{c}\text { Statutory Tax } \\
\text { Rate, Double } \\
\text { Taxation of } \\
\text { Dividends and } \\
\text { Interests }\end{array}$ & $\begin{array}{l}\text { Cross-section, } \\
\text { OLS }\end{array}$ \\
\hline $\begin{array}{l}\text { Chiorazzo \& } \\
\text { Milani (2011) }\end{array}$ & $\begin{array}{c}\text { EU } \\
(1990-05)\end{array}$ & $\begin{array}{l}\text { Bankscope } \\
\text { (8,000 banks } \\
\text { approx.) }\end{array}$ & $\begin{array}{l}\text { NIM, Pre-tax } \\
\text { profit }\end{array}$ & $\begin{array}{c}\text { Taxes / Total } \\
\text { Assets }\end{array}$ & $\begin{array}{c}\text { Dynamic panel, } \\
\text { GMM }\end{array}$ \\
\hline
\end{tabular}

Yet, this conclusion is somewhat surprising. Indeed, the theoretical literature on corporate income tax incidence is less clear than what the evidence above suggests: who pays corporate income taxes is one of the most debated questions in public finance (see Auerbach, 2006). Partial equilibrium analysis suggests that corporate income tax is not shifted forward to customers. Unlike sales tax, whose incidence depends on demand and supply elasticities, 
corporate income taxes do not affect the maximization function of the firms. ${ }^{1}$ Moreover, most of the general equilibrium models consider that the burden of the corporate income tax is borne by factor income and not by the customers and recent empirical research on incidence of corporate income taxes in the non-financial sector focuses on the effect on owners of capital or employees, but not on the customers.

Our study has two objectives. First, we would like to revisit the above empirical evidence on the pass-through of the corporate tax burden on NIM, because their results appear to contradict the theory and we argue that previous empirical studies suffer either from the endogeneity problem or from erroneous specification of the tax burden variable. Second, we would like to investigate the impact of market competition and banks' market power on the ability of banks to shift taxes to their customers. Such focus is warranted by the existing evidence that banks operate in the environment of the monopolistic competition and enjoy large markups (Claessens and Laeven, 2004; Angelini and Cetorelli, 2003; Maudos and Fernàndez de Guevara, 2004; Fernàndez de Guevara et al. 2005). To measure market power and competition, we rely on a battery of measures, such as market structure variables (i.e. Herfindal index and banks' market share) and indicators borrowed from the industrial organization literature, such as the Lerner index and the Panzar and Ross h-statistic. For our study, we rely on a dataset of 1,411 European commercial banks over the period 1992-2008. Contrary to earlier studies, we find no evidence that banks are able to shift taxes to their customers by widening the spread between lending and deposit rates. This holds even for uncompetitive markets and for banks with large market power.

The remainder of the paper is organized as follows. Section 2 provides descriptive statistics on banks' taxation and describes our dataset. Section 3 presents the econometric model. Section 4 discusses the results. Section 5 concludes.

\section{DATA}

In this study, we use data on individual banks from the Bankscope's database (Bureau Van Dijk). This database provides harmonized banks' financial statements (balance sheets and income statements) worldwide. The same database is used, for instance, by Demirgüc-Kunt and Huizinga (1999, 2001), Huizinga et al. (2011) and Chiorazzo and Milani (2011). We restrict our sample to commercial banks that operated in 17 European countries (Austria, Belgium, Denmark, Finland, France, Germany, Greece, Ireland, Italy, Luxembourg, Netherlands, Norway, Portugal, Spain, Sweden, Switzerland, the United Kingdom) for the period between 1992 and 2008.

\footnotetext{
${ }^{1}$ Corporate tax rate does not have any direct impact on the behavior of banks given that the optimization problem (that includes setting prices and quantities) is the same whether there is a corporate tax or not. However, as clearly stated by Albertazzi and Gambacorta (2010), corporate tax may have an impact on demand for loan (i.e. the higher the corporate tax, the lower the number of projects with a positive NPV) and on the cost of equity (i.e. the higher the corporate tax, the lower the net rate of return accruing to outside investors).
} 
Bankscope contains balance sheet and income statement data for a large number of European public and private banks, but not all of them are available for the whole period and detailed observations are often missing. For a given bank and year, when a useful observation is missing, we drop all the corresponding bank-year observations. In addition, we get rid of outliers by deleting the first and the last percentiles of the distribution of the following variables: NIM, Equity, Tax/profits, LLP and Costs. Alternatively, we perform an ad-hoc cleaning of the database, controlling graphically for outliers. The method to handle outliers has no impact on the results (the two methods only differ for a dozen of observations). We present results for the first treatment of the database. Lastly, we restrict our sample to banks for which the profit and taxes are positive for a given year for the reasons explained later. The sample we use in this study contains 1,411 banks or 7,938 bank-year observations. Descriptive statistics are provided in Appendix (Tables A and B).

We aim to investigate how taxes are passed on to banks' customers by increasing the spread between lending and deposit rates. Thus, our first variable of interest is the net interest margin (NIM), calculated as the bank's net interest revenue (interest income less interest expense) over total assets. The series is characterized by a mean of $2.2 \%$ and a standard deviation of $1.28 \%$. Since banks can also shift taxes by charging higher fees and commissions, we test the robustness of our results with net fees and commissions, calculated as net fees and commissions over total assets.

The second main variable in our analysis is a proxy for bank taxation (TAX). In this study, we are interested in the implicit tax rate, as opposed to the statutory corporate income tax rate. Statutory corporate income tax rate have been used by Demirgüc-Kunt and Huizinga (2001) and Albertazzi and Gambacorta (2010). However, there is evidence that the statutory tax rate does not reflect the genuine fiscal burden. First, the amount of taxes that banks have to pay depends not only on the corporate income tax rate but also on the tax base, as well as specific fiscal rules (in particular the regimes of tax carry-back and carry-forward). Second, international banks may take advantage of their cross border activities to shift their profits to minimize tax payments, the statutory tax rate does not reflect the real burden of taxation (Demirgüc-Kunt and Huizinga, 2001). Next, we present a number of figures to support our decision to rely on implicit tax rates and not statutory ones.

Figure 1.A compares the statutory corporate income tax rate and the implicit bank tax rate for the 17 European countries between 1994-2008. Bar charts represent statutory corporate tax rates; small horizontal lines correspond to weighted average values of the effective bank tax rate while vertical lines show the second and the third quartiles over the whole period. Data on statutory corporate income tax is taken from OECD, while the implicit bank tax rate is calculated with Bankscope database. In all countries, except Italy, the statutory tax rate is higher than the implicit tax rate. The weighted average ratio of tax expenses to profit in our sample varies from $19 \%$ in Portugal to $44 \%$ in Italy; this is a larger range than for statutory tax rates (21\%-42\%). Similarly, the standard deviations are $5 \%$ and $6 \%$ for statutory and implicit tax rates. Portugal appears to be an outlier in a sense that the implicit tax rate is much lower than the statutory rate $(19 \%$ and $35 \%)$. Figure 1.B presents two scatter-plots. The first one indicates that the correlation between the statutory corporate tax rates (on the $\mathrm{x}$-axis) and the weighted average implicit bank tax rates (on the y-axis) is weak, which supports our 
decision to rely on implicit tax rates. The second scatter-plot represents the weighted average implicit tax rates on the x-axis, computed with our sample, and the implicit tax rates computed using aggregated OECD data over the same period on the y-axis. $\mathrm{R}^{2}$ of this relationship equals to $64 \%$, which indicates that the strength of this relationship is high and gives us confidence that our sample is representative. Figure 1 has already shown that the differences between tax rates are often more important between banks within a country, than between countries. Figure 2 further supports this claim by documenting a considerable variation of implicit tax rates between large banks from the same country.

Figure 1. Statutory and implicit tax rates in 17 European countries

A. This figure represents the average statutory corporate tax rate (bar charts) and the implicit bank tax rate (the horizontal line correspond to the weighted average value and the vertical line to the second and the third quartiles) over the period 1994-2008.

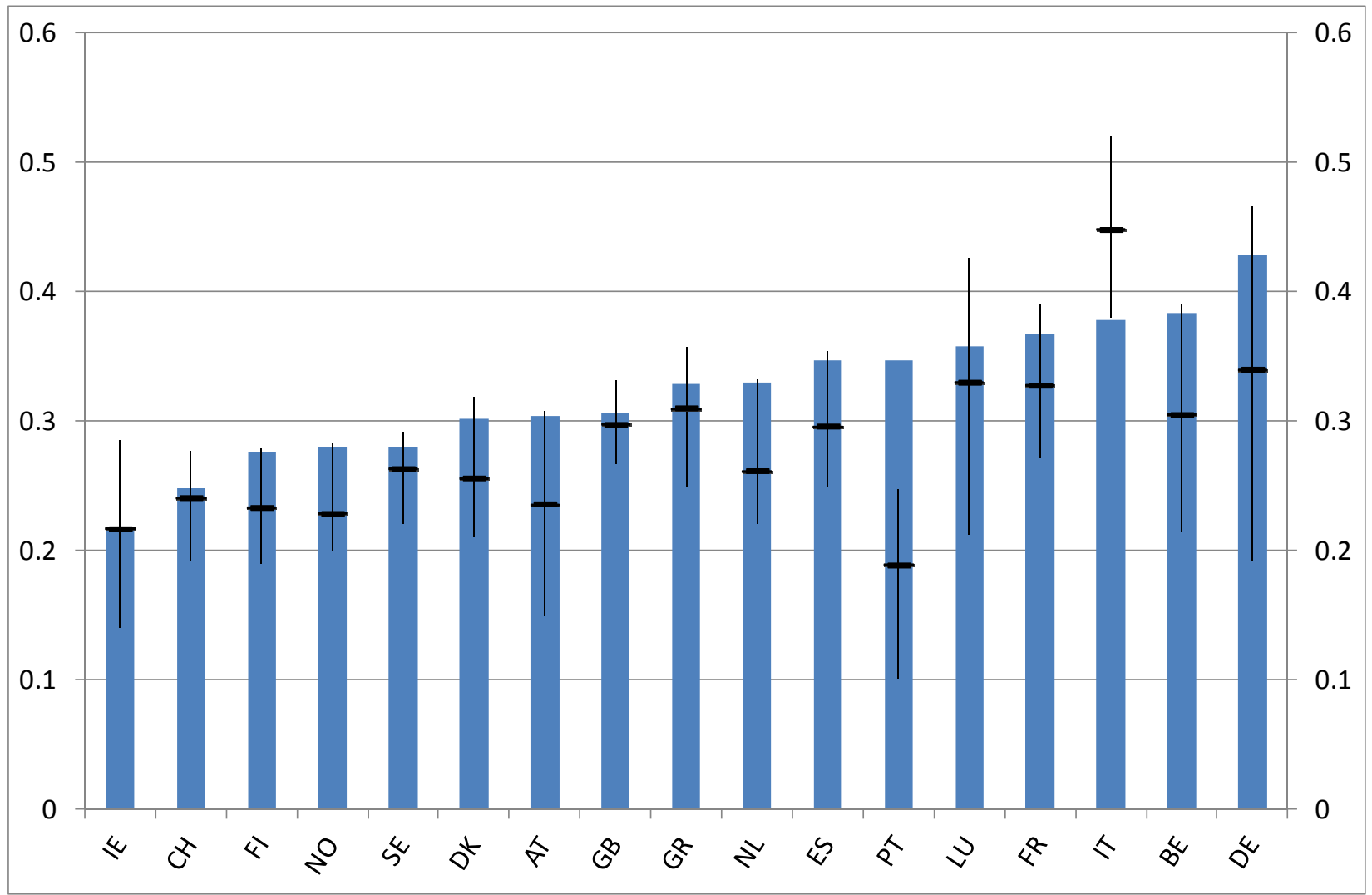


B. Relationship between average statutory corporate tax rates and average implicit tax rates computed with the OECD and Bankscope data.

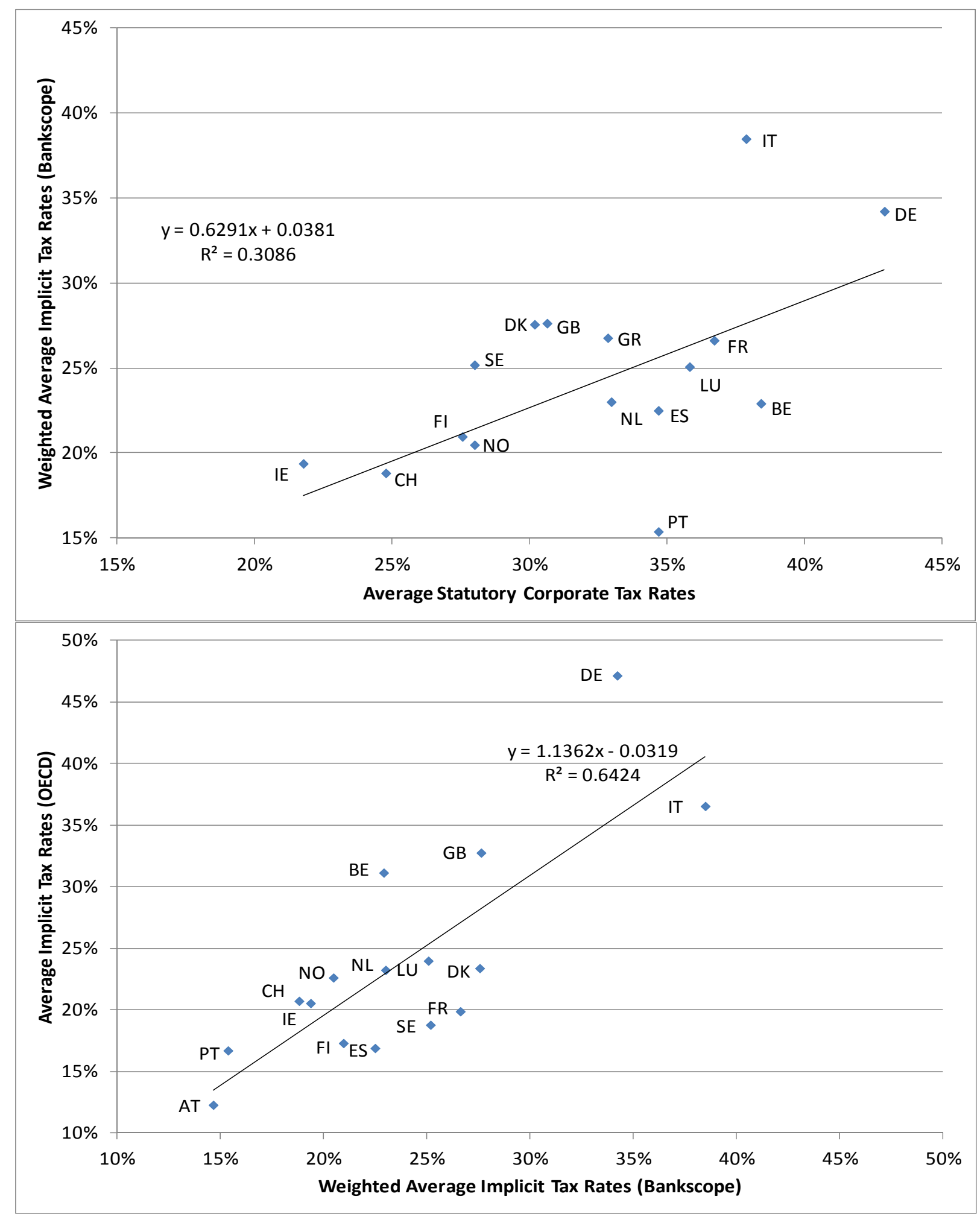

Source: Bankscope; Huizinga et al. (2011). Authors’ calculation. 


\section{Figure 2. Average implicit tax rates for the largest banks in Europe and North-America (2005-2010)}

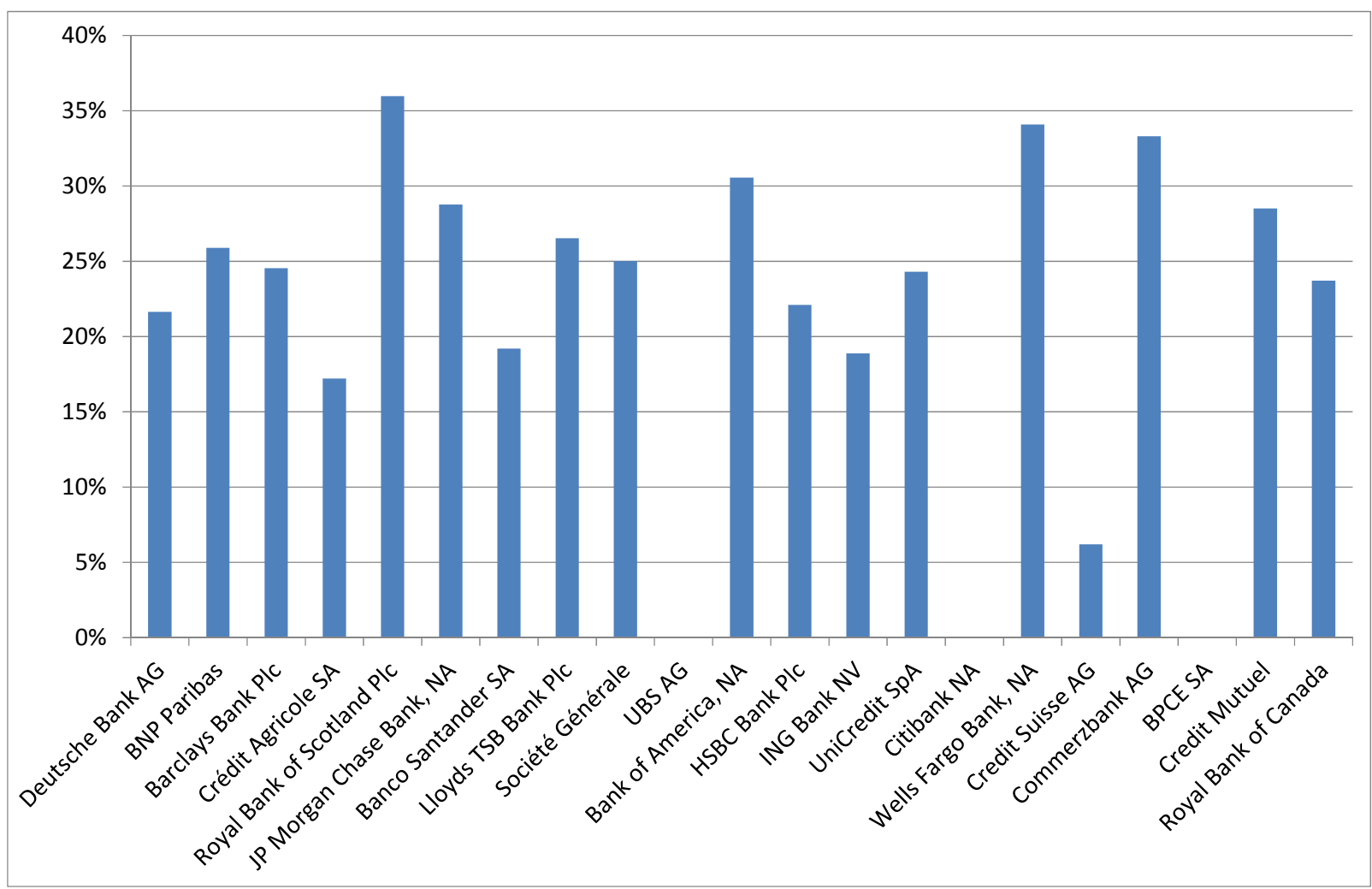

Source: Bankscope. For UBS, Citibank and BPCE, the average implicit tax rate is negative and, consequently, not reported. Authors' calculation.

In Figure 3, we show the evolution of statutory and implicit tax rates over the observed period of 1992-2008. Both rates have decreased as countries have chosen to decrease the tax burden on enterprises. However, the implicit tax rate remains consistently below the statutory rate. These results (that rely on Bankscope data) are corroborated by the OECD data that allows seeing that declining implicit tax rates constitute a long-term trend. In fact, profits of the financial sector in OECD countries have grown at a higher rate than banks' income taxes, leading to a sharp decrease of the implicit tax rate, from $40 \%$ in the late 1980 s to $20 \%$ before the crisis (Figure 4).

Since implicit tax rates reflect better the banks' tax burden, most recent studies rely on implicit tax rates. For example, Chiorazzo and Milani (2011) compute it as the ratio of tax expenses to total assets. The problem is that such measure can lead to a spurious regression between NIM and tax-to-assets ratio, because both dependent and independent variables are constructed with assets in the denominator. Hence, they are related to each other by construction. Second, the inclusion of this variable could lead to the simultaneity bias, because both NIM and tax-to-assets ratio are simultaneously influenced by economic conditions and profit opportunities that are difficult to control for. Although the endogeneity 
stemming from this simultaneity problem can be corrected econometrically by the system GMM, the first problem would remain.

\section{Figure 3. The evolution of implicit and statutory tax rates over 1994-2008.}

This figure represents the weighted average statutory corporate tax rate and the weighted average implicit bank tax rate over the period 1994-2008 for the whole sample.

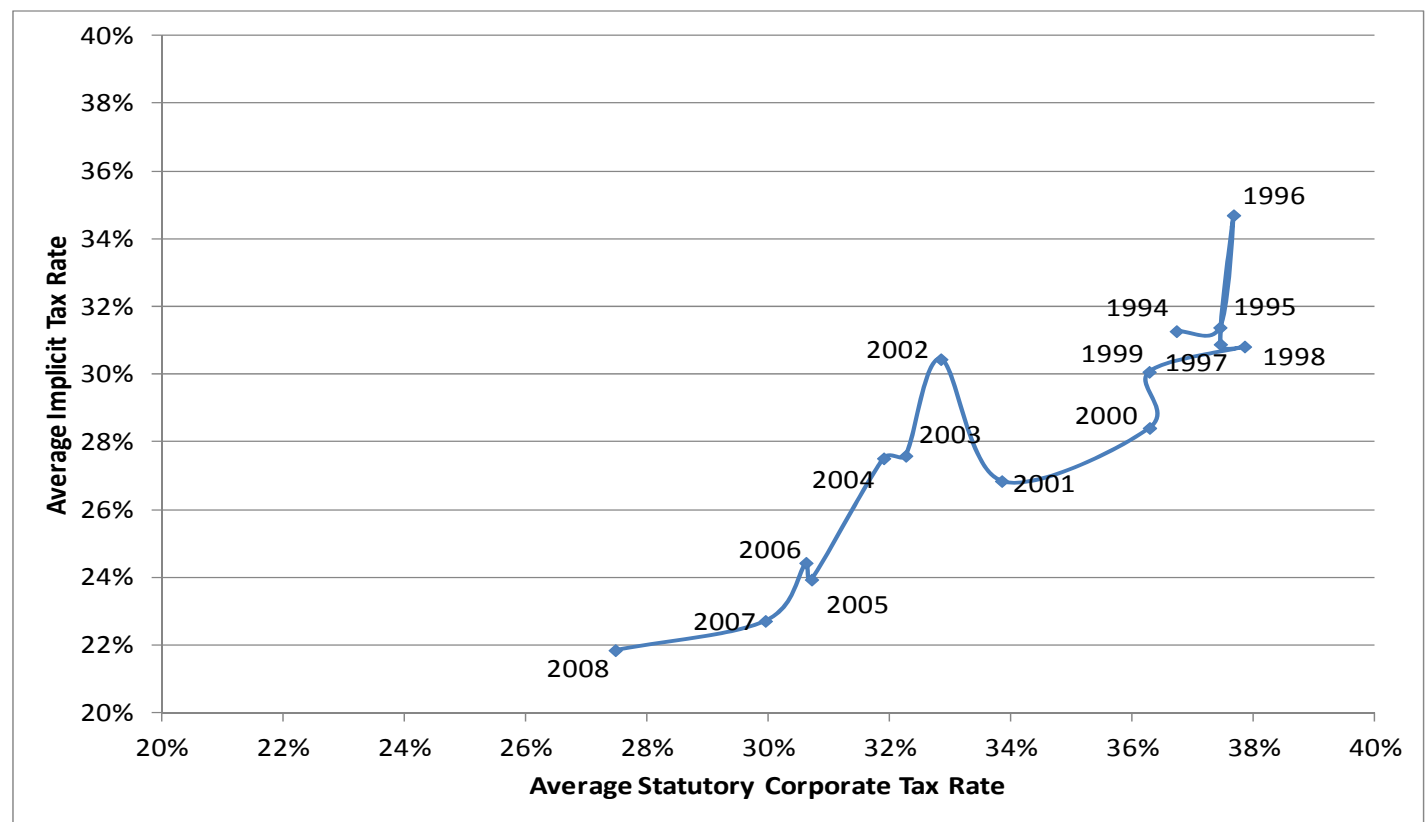

Source: Bankscope. Authors’ calculation.

Figure 4. Bank implicit tax rates for the main OECD countries

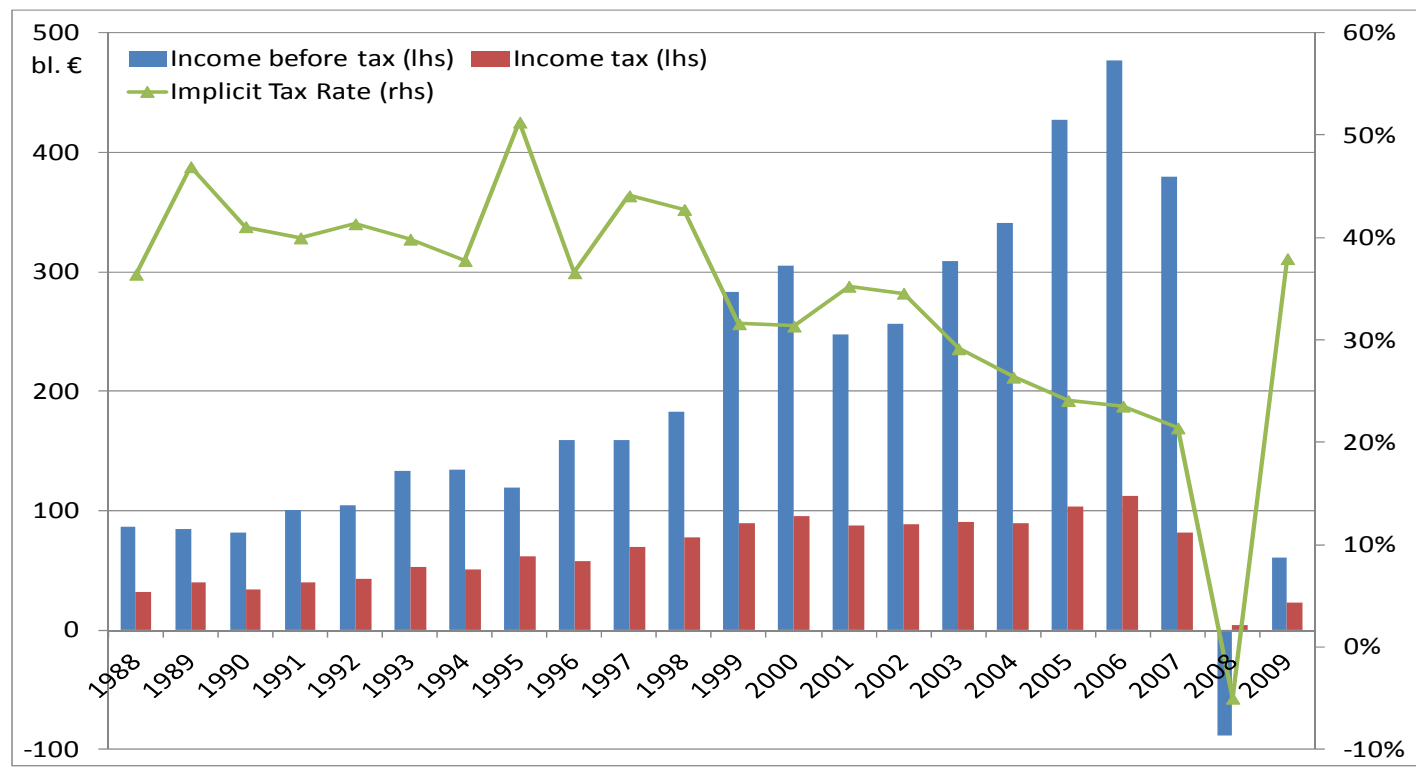

Source: OECD (Bank Profitability Statistics, Income Statement and Balance Sheet). The list of countries included: Austria, Belgium, Canada, Denmark, Finland, France, Germany (until 2008), Ireland (since 1995), Italy, Luxembourg, Norway, Netherlands, Portugal, Sweden, Switzerland, the United Kingdom (until 2008), and the United States. Authors' calculation. 
In contrast, Demirgüc-Kunt and Huizinga (2001) compute the implicit tax rate for each bank by dividing paid taxes by pre-tax profits. Importantly, they average this variable for each bank over the observed period in order to preclude that a positive relationship between pre-tax profitability and the tax rate simply reflects an increasing marginal taxation of bank profits. The drawback of such approach is that this variable is time invariant. Hence, such regression cannot be estimated with fixed effects at the bank level and, moreover, this variable takes the role of the fixed effect and can include any bank characteristic that is not captured by other explanatory variables, thus suffering from the endogeneity problem due to missing variable bias.

In this study, we compute the implicit tax rate, calculated as the ratio of tax expenses to pretax profits computed for each bank and each year. This ratio is directly comparable with the statutory tax rate because it has the same denominator. Since this variable only makes sense if profits and taxes are positive, we restrict our sample to profitable institutions that pay taxes. The ratio of taxes to profits should be less influenced by economic conditions than the ratio of taxes to assets, thus limiting endogeneity problems due to simultaneity. ${ }^{2}$ As it is time variant, we can rely on different econometric techniques, such as system GMM estimator to tackle its potential endogeneity related to the fact that it is constructed from the same balance sheet as NIM.

\section{Methodology}

\subsection{The econometric model}

We propose to investigate whether the burden of taxation is passed through by banks to their customers by following literature on NIM determinants and estimating the following models:

$N I M_{i, t}=\alpha+\beta N_{I M} M_{i, t-1}+\gamma$ Tax/profits $i, t+\delta X_{i, t}+\lambda_{t}+\varepsilon_{i, t}$

where NIM is the net interest margin (calculated as the difference between interest income and interest expenses, relative to total assets), Tax/profits is the implicit tax rate, i.e. the ratio of tax expenses to pre-tax profits, $X$ is a set of controls, $\lambda_{t}$ is a time dummy. The set of controls $X$ is composed of macroeconomic variables (GDP growth, inflation) and several bank characteristics: capital ratio (equity over total assets), risk (value of loans loss provisions over total assets), cost efficiency (measured by the ratio of non-interest expenses to assets), size (log of total assets). For variable that divide a flow variable on a stock variable, we construct the denominators as the mean of the variable between $t$ and $t-1$. Exact variable definitions, data sources and descriptive statistics are reported in the Appendix A. We estimate this equation by relying on the system GMM estimators developed in Arellano and Bond (1991)

\footnotetext{
${ }^{2}$ If banks were always profitable and were not able to shift taxes across time periods due to tax regimes that allow the carry-back and carry-forward for profits, the tax-to-profit ratio would be independent of economic conditions.
} 
and Blundell and Bond (1998). We test the robustness of our results with Fees as dependent variable (calculated as net fees and commissions relative to total assets).

\subsection{The source of heterogeneity: market power and competition}

We next proceed to investigate a potential heterogeneity between banks in the pass-through depending on the market power and competition:

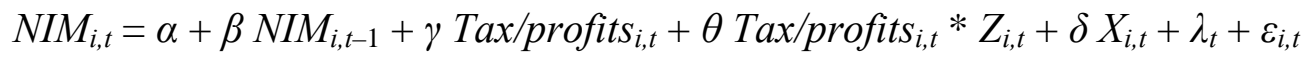

where $T A X_{i, t} * Z_{i, t}$ is an interaction variable between $T A X_{i, t}$ and different measures of market power and competition, $Z_{i, t}$.

\section{Market share and market structure indicators}

Assuming that more concentrated markets lead to less competition (structure-conductperformance paradigm), the easiest way to measure market competition is to rely on market structure measures and, hence, we include bank's market share (in terms of assets, loans or deposits), and the Herfindhal-Hirschman index ( $\mathrm{HH})$. $\mathrm{HH}$ index is a commonly accepted measure of market concentration and is defined as the sum of the squares of the market shares of each bank within the country. $\mathrm{HH}$ index ranges from 0 to 1 . An increase in $\mathrm{HH}$ index is associated with a decrease in competition. This index is also computed in terms of assets, loans and deposits.

Similarly, we interact taxation with bank size, as bank size has served as an important threshold in taxation decisions. In most countries that have implemented or consider implementing a bank levy (the US, the UK, France and Germany), small banks are exempt from a levy or pay a lower rate ${ }^{3}$. Theoretically, such progressive taxation is related to the moral hazard caused by the bailout of too-big-to-fail financial institutions. Another underlying reason for such progressive taxation is to ensure that banks do not pass taxes to their clients: if large banks decide to increase their lending rates, borrowers can go to smaller banks. Such approach assumes that bank size and market power are synonymous.

Alternatively, the theory of contestable markets suggests that one can have competitive markets even in concentrated systems, whereas collusive actions can be undertaken even in the presence of many firms (Claessens and Laven, 2004). Hence, one should consider measures that econometrically estimate the actual conduct of banks (Panzar and Rosse hstatistic) or actual margins (Lerner index). The actual behavior of banks is related not only to the market structure, but also to entry barriers, activity restrictions, and the degree of the competition from other forms of financial intermediation. The actual margins might additionally reflect the quality of the countries' information and judicial system.

\footnotetext{
${ }^{3}$ In this regard, the statement of President Obama on January 14, 2010 was very clear: "[The fee] will not be a cost borne by community banks or small firms; only the largest firms with more than $\$ 50$ billion in assets will be affected."
} 
Lerner index is defined as $(p-m c) / p$ where $p$ is the price of assets and $m c$ is the marginal cost of assets. The Lerner index ranges from 0 to 1 ; the higher the index, the higher the market power. The price of assets is the sum of interest income, other operating income, net fees and commissions and non-interest expenses, relative to total assets. We compute marginal costs relying on the stochastic frontier approach that is assumed to take a translog function. Hence, we measure how close a bank is to the cost frontier by following Fang, Hasan and Marton (2010):

$$
T C_{i, t}=f\left(X_{i, t}, P_{i, t}, Z_{i, t}\right)+v_{i, t}+u_{i, t}
$$

where $T C_{i, t}$ is total operating cost, $X_{i, t}$ represent output (total assets), $P_{i, t}$ - input prices (price of borrowed funds, labour and physical capital) and $Z_{i, t}$ - fixed inputs (equity).

\section{Panzar and Rosse h-statistic}

Our final measure of market competition is the h-statistic introduced by Panzar and Rosse (1987) to test for the existence of monopoly equilibrium. It is equal to the sum of the factor price elasticities of a banks' reduced form revenue equation that is estimated following Claessens and Laeven (2004):

$R_{i, t}=\alpha+\beta_{1}$ pdep $_{i, t}+\beta_{2}$ plab $_{i, t}+\beta_{3}$ pcap $_{i, t}+\gamma X_{i, t}+\lambda_{t}+\varepsilon_{i, t}$

where $R_{i, t}$ is the bank revenue, measured by the ratio of interest income to total assets (in log), pdep $_{i, t}$ is the price of deposits, measured by the ratio of total interest expenses to total funding (in log), $p l a b_{i, t}$ is the price of labour, measured by the ratio of personnel expenses to total assets, pcap $_{i, t}$ is the price of capital, measured by the ratio of other operating expenses to fixed assets (in log), $X$ is a set of controls composed by the ratio of loans to total assets (log), the ratio of equity to total assets (log) and the size of the bank (log of total assets). $\lambda_{t}$ is a year dummy. We compute h-stat as the sum of $\beta_{1}, \beta_{2}$, and $\beta_{3}$. We run this equation separately for each country.

Computing h-stat, we quantify what will be the percentage change in equilibrium revenues resulting from a $1 \%$ change in all factor prices. Under monopoly, an increase in input prices increases marginal costs, reduces equilibrium output, and consequently lowers total revenues. Under perfect competition, an increase in input prices raises both marginal costs and total revenues by the same amount. Accordingly, the h-statistic is interpreted as follows: h-stat $<0$ indicates monopoly, $0<\mathrm{h}$-stat $<1$ monopolistic competition and h-stat $=1$ perfect competition.

Our different proxies for market power and competition are expected to be connected, albeit not perfectly correlated. For instance, in Claessens and Laeven (2004), the correlation between the h-statistic and the market concentration (computed as the total market share of the fifth largest banks in each country) is of 38\%. In our sample, estimates lead to similar relationships. Thus, the correlation (at the country level) between the $\mathrm{HH}$ index and the Lerner index is of $10 \%$, while the correlation between the Lerner index and the h-statistic is 
of 35\% (in absolute value). These statistics confirm both the difficulty of measuring market power and the need for a large set of proxies.

\section{EMPIRICAL RESULTS}

\subsection{The impact of taxation on nominal interest margins}

Before proceeding to the estimation of our baseline model (1), we present four different specifications of the model that differ with respect to the measure of taxation burden and econometric technique (Table 1). Following Demirgüc-Kunt and Huizinga (1999), in column 1 , we measure the tax burden by the implicit tax rate averaged over the observed period, and to ensure comparability of the results, all variables are contemporaneous and the model is estimated with OLS. The specification in column (2) differs from column (1) insofar as we do not average the implicit tax rate and, thus, keep it time-variant. The results of these two specifications are broadly in line with Demirgüc-Kunt and Huizinga (1999): we find a positive coefficient in both of these models, suggesting that banks pass through their taxes to customers by increasing interest margins. As these models are estimated with simple OLS, they do not attempt to control for endogeneity. Thus, in column (3), we present the specification with lagged bank characteristics and estimate it with bank level fixed effects. The results show that even after such control for endogeneity, the effect of banks' taxes on NIM is no longer statistically significant.

Column (4) reports the specification where the tax burden is measured as a ratio of paid taxes over total bank's assets, which corresponds to the definition introduced by Chiorazzo and Milani (2011). To ensure comparability of the results, we also estimate our model with Arrelano-Bover system GMM. This method allows us to estimate a dynamic model of NIM and to control for endogeneity of the tax variable. In line with Chiorazzo and Milani (2011), we find that in a short-run banks shift $49 \%$ of their taxes to customers by widening their interest margins. However, as mentioned earlier, such regression might suffer from two problems. First, NIM and tax-to-assets ratio can be correlated by construction because they both contain assets in denominator and this problem cannot be corrected with Arrelano-Bover system GMM. Second, the model suffers from simultaneity bias if we do not control sufficiently for profit opportunities that effect at the same time interest margins and profits. Even though this problem can be corrected theoretically with system GMM, it is more prudent to choose an explanatory variable that suffers less from endogeneity problems, as we propose to do it in the next model.

Hence, in column (5) we report the results of our preferred specification and econometric methodology: The tax burden is measured as an implicit tax rate (paid taxes divided by pretax profits) and the model is estimated with system GMM to control for any potential endogeneity (Arellano and Bover, 1995; Blundell and Bond, 1998). We consider $\mathrm{NIM}_{\mathrm{t}-1}$, Equity and Tax/profits as endogenous variables, in line with Chiorazzo and Milani (2011). As suggested by Roodman (1996), we introduce year dummies, but we omit country dummies that might bias the results in system GMM if the number of time periods is small. As 
instrument proliferation can overfit endogenous variables, fail to expunge their endogenous components and also weaken the power of the Hansen test to detect this very problem, we attempt to limit the number of instruments by limiting the number of lags and collapsing them. Our choice is different for $\mathrm{NIM}_{\mathrm{t}-1}$ and other endogenous variables (Equity and Tax/profits) and we report our separate choices and number of instruments at the bottom of Table 1. We also show that our model passes the Hansen test of over-identifying restrictions and Arellano-Bond test of residuals' auto-correlation of order 2 at $1 \%$ significance level. ${ }^{4}$

According to this specification, the coefficient of the Tax/profits variable is not statistically significant and, thus, we do not find that banks are able to shift their tax burden to customers by widening the wedge between the lending rate and the deposit rate. As it is explained above, our results contradict earlier findings because they do not control for endogeneity (DemirgüçKunt and Huizinga, 1999) or are biased due to the erroneous construction of the measure of tax burden (Chiorazzo and Milani, 2011). If we apply the same approaches as these earlier papers, we are able to reproduce their results, suggesting that our findings are not driven by sample differences.

As far as other control variables are concerned, they have the expected sign and our results are in line with earlier empirical studies on NIM determinants (Demirgüç-Kunt and Huizinga (1999) or Claeys and Vander Vennet (2008)). The positive sign of the ratio of bank's equity over total assets is consistent with the fact that the financing cost of well capitalized banks is lower. The ratio of loan loss provisions over total assets has a positive and significant effect, which supports the idea that NIM is a compensation for risk taking. Similarly, we observe that higher costs and larger market share in assets widen NIM as well. As to macroeconomic controls, we find that an increase of the inflation rate increases significantly the NIM, as banks raise their lending rates faster than deposit rates. Finally, we show that in more concentrated markets, NIM is lower, which can be surprising if one associates market concentration with the strength of competition. However, such naïve approach is often questioned after Claessens and Laeven (2004) have shown that concentration and competition are not necessarily related, and are sometimes even positively correlated (more concentrated markets are more competitive).

Finally, in column (6) we test the robustness of our results with Fees as dependent variable. Besides the difference in the dependent variable, the specification is identical to column 5 . Our results show that higher taxes do not lead to wider fees margin, hence, we confirm our previous findings that banks do not shift taxes to their clients.

\subsection{Accounting for bank heterogeneity}

As it was discussed in the Introduction, the theory suggests that the degree of the competition could affect the ability of banks to shift their tax burden by widening the NIM. Benefiting from market power allows compressing interest expenses on funding as well as increasing interest rates on loans. To account for such phenomena, we interact our measure of implicit tax rate with different indicators of market power and competition. We first discuss the results

${ }^{4}$ In Table 2, we re-estimate this model for several countries or group of countries. 
of Table 3, where we look at the effect of size, market share and HH index in terms of assets, loans and deposits. Our results show the coefficient on Tax/profits is still not significant, and we find no effect of bank size or market share on the ability of banks to shift their taxes. At the same time, we find that banks in more concentrated markets are more likely to pass taxes to their clients. Importantly, we confirm our earlier findings that NIM is lower in more concentrated markets. Considered together, these findings do not allow us to associate market concentration with weak competition, because theoretically weak competition should result in both wider NIM and higher pass through of taxes.

Given the ambiguity of our findings, we propose to use alternative measures of market competition and market power by relying on indicators borrowed from the industrial organization literature, such as Panzer and Ross (1989) h-statistic and Lerner index. Our results, reported in Table 4, do not show that these variables influence the ability of banks to shift taxes to customers. At the same time, the inclusion of the Lerner index affects the significance of Tax/profits variable, which becomes significant at $10 \%$ level. This change is due to a different data sample, as the construction of the Lerner index requires data on a large number of variables and, consequently, shortens the number of available banks and observations in our sample.

\section{CONCLUSION}

Our study investigates the ability of banks to shift their tax burden to customers by widening their net interest margins and whether it depends on market competition and bank's market power. The question of tax incidence is important inasmuch as one would like to know who bears the burden of banks' taxation: shareholders, employees or customers. If banks are able to pass their taxes to clients, an increase in taxes would increase borrowing costs for enterprises and borrowers without diminishing banks' profits. This would be contrary to the objective of policy makers who would like to tax banks to recuperate bail-out costs related to the crisis and to tax banks' economic rents due to implicit bail-out guarantees in the future.

Our results show that, on average, banks do not pass their taxes to clients by widening their net interest margins and this lack of tax incidence is not affected by market competition and banks' market power. This suggests that the burden of banks' taxes would be effectively born by banks (shareholders or employees). Our findings differ from other studies that find a large pass-through because earlier studies do not control for endogeneity (Demirgüç-Kunt and Huizinga, 1999) or suffer from the erroneous construction of the tax variable (Chiorazzo and Milani, 2011).

It is important to underline that Bankscope database allows us to calculate NIM, market power and the degree of the competition on an aggregated basis, overlooking the market segmentation (retail vs. wholesale, urban vs. rural areas, etc.). As some market segments are less competitive than others, the figure for an average pass-through hides the fact that even an 
average bank might shift all its taxes to customers that are "locked-in", such as individual borrowers and SMEs, while sparing large enterprises that are more mobile. Thus, more research is needed with the disaggregated data for different types of customers. 


\section{REFERENCES}

Albertazzi, U., \& L. Gambacorta, 2010. Bank profitability and taxation, Journal of Banking \& Finance, 34(11), 2801-2810.

Angelini, P. \& N. Cetorelli, 2003. The effects of regulatory reform on competition in the banking industry, Journal of Money, Credit and Banking, 35 (5), 663-84.

Arellano, M. and O. Bover. 1995. Another look at the instrumental variable estimation of errorcomponents models, Journal of Econometrics, 68, 29-51.

Auerbach, A., 2006. Who bears the corporate tax? A review of what we know, in J.M. Poterba (ed.), 'Tax Policy and the Economy”, Volume 20, The MIT Press.

Blundell, R., \& S. Bond, 1998. Initial conditions and moment restrictions in dynamic panel data models, Journal of Econometrics, 87, 115-143.

Caminal, R., 2003. Taxation of Banks; Modeling the Impact, in P. Phonohan (ed.), "Taxation of financial intermediation: Theory and practice for emerging economies". The World Bank and Oxford University Press, 31-80.

Chiorazzo, V. and C. Milani, 2011. The impact of taxation on bank profits: Evidence from EU banks, Journal of Banking and Finance, 35, 3202-3212.

Claessens, S., \& L. Laeven, 2004. What drives bank competition ? Some international evidence, Journal of Money, Credit and Banking, 36, 563-83.

Claeys, S., \& R. Vander Vennet, 2008. Determinants of bank interest margins in Central and Eastern Europe: A comparison with the West. Economic Systems, 32(2), June, 197-216.

Demirgüc-Kunt, A., \& H. Huizinga, 1999. Determinants of commercial bank interest margins and profitability: Some international evidence. World Bank Economic Review, Oxford University Press, 13(2), 379-408.

Demirgüc-Kunt, A., \& H. Huizinga, 2001. The taxation of domestic and foreign banking, Journal of Public Economics, 79, 429-453.

European Commission, 2010. Financial sector taxation. DG TAXUD, Taxation Paper, 25.

European Commission, 2012a. Review of Current Practices for Taxation of Financial Instruments, Profits and Remuneration of the Financial Sector. DG TAXUD, Taxation Paper, 31 - 2012.

European Commission, 2012b. Tax elasticities of financial instruments, profits and remuneration: Review of the economic literature. DG TAXUD, Taxation Paper, 30.

Fang, Y., I. Hasan, and K. Marton, 2010. Efficiency of banks in transition: Recent evidence from South and Eastern Europe, Bank of Finland Research Discussion Papers.

Fernández de Guevara, J., J. Maudos and F. Pérez, 2005. Market power in European banking sectors, Journal of Financial Services Research, 27(2), 109-13.

Huizinga, H.P., 2002. A European VAT on financial services? Economic Policy, 17(35), 498-534.

Huizinga, H.P., J. Voget \& W. Wagner, 2011. International taxation and cross-border banking, CEPR Discussion Papers, 8436.

International Monetary Fund, 2010, A fair and substantial contribution by the financial sector, Final report for the $G-20$, Washington, DC. 
Maudos, J., \& J. Fernández de Guevara, 2004. Factors explaining the interest margin in the banking sectors of the European Union, Journal of Banking \& Finance, 28(9), 2259-2281.

Panzar, J., \& J. Rosse, 1987. Testing for “monopoly” equilibrium, Journal of Industrial Economics, 4, 443-456. 
Table 1. The impact of taxes on NIM and fees margin

\begin{tabular}{|c|c|c|c|c|c|c|}
\hline & & & NIM & & & Fees \\
\hline & 1 & 2 & 3 & 4 & 5 & 6 \\
\hline NIM $_{t-1}$ & & & & $\begin{array}{l}0.57^{* * *} \\
(0.08)\end{array}$ & $\begin{array}{l}0.57^{* * *} \\
(0.05)\end{array}$ & \\
\hline Fees $_{t-1}$ & & & & & & $\begin{array}{c}0.44^{*} \\
(0.26)\end{array}$ \\
\hline Tax (average) & $\begin{array}{c}0.01^{* * *} \\
(0.0009)\end{array}$ & & & & & \\
\hline Tax/profit & & $\begin{array}{l}0.004^{* * *} \\
(0.0007)\end{array}$ & $\begin{array}{c}0.003 \\
(0.005)\end{array}$ & & $\begin{array}{c}0.001 \\
(0.0009)\end{array}$ & $\begin{array}{c}0.009 \\
(0.0008)\end{array}$ \\
\hline Tax/assets & & & & $\begin{array}{l}0.49^{* * *} \\
(0.18)\end{array}$ & & \\
\hline Equity & $\begin{array}{l}0.03^{* * *} \\
(0.003)\end{array}$ & $\begin{array}{l}0.02^{* * *} \\
(0.002)\end{array}$ & $\begin{array}{l}0.02^{* * *} \\
(0.002)\end{array}$ & $\begin{array}{l}0.04^{* * *} \\
(0.01)\end{array}$ & $\begin{array}{l}0.04^{* * *} \\
(0.009)\end{array}$ & $\begin{array}{l}0.03^{* * *} \\
(0.01)\end{array}$ \\
\hline Costs & $\begin{array}{l}0.59^{* * *} \\
(0.015)\end{array}$ & $\begin{array}{l}0.58^{* * *} \\
(0.02)\end{array}$ & $\begin{array}{l}0.32^{* * *} \\
(0.02)\end{array}$ & $\begin{array}{l}0.14^{* * *} \\
(0.05)\end{array}$ & $\begin{array}{l}0.29^{* * *} \\
(0.05)\end{array}$ & $\begin{array}{l}0.48^{*} \\
(0.25)\end{array}$ \\
\hline Size & $\begin{array}{c}-0.001^{* * *} \\
(0.0007)\end{array}$ & $\begin{array}{c}-0.001^{* * *} \\
(0.0007)\end{array}$ & $\begin{array}{c}-0.002^{* * *} \\
(0.0002)\end{array}$ & $\begin{array}{c}0.0001 \\
(0.0002)\end{array}$ & $\begin{array}{r}-0.00004 \\
(0.0001)\end{array}$ & $\begin{array}{c}0.0003^{* * *} \\
(0.0001)\end{array}$ \\
\hline LLP & $\begin{array}{l}0.006^{* * *} \\
(0.0006)\end{array}$ & $\begin{array}{l}0.006^{* * *} \\
(0.0006)\end{array}$ & $\begin{array}{l}0.0002 \\
(0.00)\end{array}$ & $\begin{array}{l}0.003^{* * *} \\
(0.0007)\end{array}$ & $\begin{array}{l}0.002^{* * *} \\
(0.0005)\end{array}$ & $\begin{array}{c}0.001^{* *} \\
(0.0006)\end{array}$ \\
\hline Assets share & $\begin{array}{l}0.01^{* * *} \\
(0.003)\end{array}$ & $\begin{array}{c}0.009^{* * *} \\
(0.003)\end{array}$ & $\begin{array}{l}-0.008^{*} \\
(0.004)\end{array}$ & $\begin{array}{l}0.0008 \\
(0.002)\end{array}$ & $\begin{array}{l}0.004^{*} \\
(0.002)\end{array}$ & $\begin{array}{c}-0.009^{* *} \\
(0.004)\end{array}$ \\
\hline HHI assets & $\begin{array}{l}-0.005 \\
(0.003)\end{array}$ & $\begin{array}{l}-0.005 \\
(0.003)\end{array}$ & $\begin{array}{l}-0.003^{*} \\
(0.001)\end{array}$ & $\begin{array}{l}-0.003^{*} \\
(0.002)\end{array}$ & $\begin{array}{c}-0.007^{* * *} \\
(0.002)\end{array}$ & $\begin{array}{c}0.002 \\
(0.004)\end{array}$ \\
\hline GDP growth & $\begin{array}{l}0.03^{* * * *} \\
(0.01)\end{array}$ & $\begin{array}{l}0.03^{* * * *} \\
(0.01)\end{array}$ & $\begin{array}{l}0.02^{* * * *} \\
(0.005)\end{array}$ & $\begin{array}{l}0.02^{* * *} \\
(0.005)\end{array}$ & $\begin{array}{l}-0.005 \\
(0.006)\end{array}$ & $\begin{array}{l}0.03^{* *} \\
(0.01)\end{array}$ \\
\hline Inflation & $\begin{array}{l}0.03^{* * *} \\
(0.01)\end{array}$ & $\begin{array}{l}0.03^{* * *} \\
(0.01)\end{array}$ & $\begin{array}{l}0.03^{* * *} \\
(0.006)\end{array}$ & $\begin{array}{l}0.007^{*} \\
(0.004)\end{array}$ & $\begin{array}{l}0.03^{* * *} \\
(0.009)\end{array}$ & $\begin{array}{l}-0.03^{* *} \\
(0.01)\end{array}$ \\
\hline Constant & $\begin{array}{l}0.02^{* * *} \\
(0.001)\end{array}$ & $\begin{array}{l}0.02^{* * * *} \\
(0.001)\end{array}$ & $\begin{array}{l}0.04^{* * *} \\
(0.001)\end{array}$ & $\begin{array}{l}-0.0004 \\
(0.003)\end{array}$ & $\begin{array}{c}0.002 \\
(0.002)\end{array}$ & $\begin{array}{c}-0.006^{* * *} \\
(0.001)\end{array}$ \\
\hline Country dummies & Yes & Yes & No & No & No & No \\
\hline Year dummies & Yes & Yes & Yes & Yes & Yes & Yes \\
\hline Observations & 7,938 & 7,938 & 7,529 & 7,938 & 7,938 & 7,793 \\
\hline Number of banks & 1,411 & 1,411 & 1,345 & 1,411 & 1,411 & 1,398 \\
\hline R-squared & 0.52 & 0.52 & 0.33 & & & \\
\hline Arrelano-Bond test AR (2) p-value & & & & 0.29 & 0.43 & 0.13 \\
\hline Hansen Test & & & & 0.27 & 0.17 & 0.13 \\
\hline Number of instruments & & & & 46 & 30 & 36 \\
\hline Lags for GMM instruments $\left(\mathrm{NIM}_{\mathrm{t}-1}\right)$ & & & & 3 & 1 & 6 \\
\hline Lags for GMM instruments (other variables) & & & & $2-3$ & $1-2$ & $1-5$ \\
\hline
\end{tabular}

Standard errors appear in parenthesis. Estimation of models 1-2 is performed with OLS, model 3 - panel data with fixed effects for banks, and models 4-5 - two-step Arrelano-Bover estimator (system-GMM) with robust standard errors. *** $\mathrm{p}<0.01, * * \mathrm{p}<0.05, * \mathrm{p}<0.1$ 
Table 2. The impact of taxes on NIM breakdown by country

\begin{tabular}{|c|c|c|c|c|c|c|c|c|c|}
\hline & FR & $\mathrm{DE}$ & IT & $\mathrm{SH}$ & $\mathrm{LU}$ & ES, PT, GR & DK, FI, NO, SE & $\mathrm{AT}, \mathrm{BE}, \mathrm{NL}$ & GB, IE \\
\hline NIM $_{t-1}$ & $\begin{array}{l}0.45^{* * *} \\
(0.09)\end{array}$ & $\begin{array}{l}0.61^{* * *} \\
(0.21)\end{array}$ & $\begin{array}{l}0.76^{* * *} \\
(0.15)\end{array}$ & $\begin{array}{l}0.65^{* * *} \\
(0.19)\end{array}$ & $\begin{array}{l}0.79^{* * *} \\
(0.06)\end{array}$ & $\begin{array}{l}0.37^{* *} \\
(0.16)\end{array}$ & $\begin{array}{l}0.81^{* * *} \\
(0.11)\end{array}$ & $\begin{array}{c}0.91 \\
(0.65)\end{array}$ & $\begin{array}{l}0.73^{* * *} \\
(0.17)\end{array}$ \\
\hline Tax/profit & $\begin{array}{c}0.003 \\
(0.003)\end{array}$ & $\begin{array}{c}0.003 \\
(0.002)\end{array}$ & $\begin{array}{c}0.003 \\
(0.002)\end{array}$ & $\begin{array}{l}0.008 \\
(0.03)\end{array}$ & $\begin{array}{l}-0.004 \\
(0.002)\end{array}$ & $\begin{array}{c}0.001 \\
(0.004)\end{array}$ & $\begin{array}{c}0.01 \\
(0.008)\end{array}$ & $\begin{array}{c}0.01 \\
(0.01)\end{array}$ & $\begin{array}{l}0.005 \\
(0.02)\end{array}$ \\
\hline LLP & $\begin{array}{c}0.002 \\
(0.002)\end{array}$ & $\begin{array}{c}0.002 \\
(0.001)\end{array}$ & $\begin{array}{l}0.0009 \\
(0.003)\end{array}$ & $\begin{array}{l}0.0003 \\
(0.002)\end{array}$ & $\begin{array}{l}0.002^{* * *} \\
(0.0007)\end{array}$ & $\begin{array}{l}0.0008 \\
(0.002)\end{array}$ & $\begin{array}{c}0.005 \\
(0.003)\end{array}$ & $\begin{array}{c}0.003 \\
(0.003)\end{array}$ & $\begin{array}{c}0.001 \\
(0.003)\end{array}$ \\
\hline Costs & $\begin{array}{l}0.39^{* * *} \\
(0.08)\end{array}$ & $\begin{array}{l}0.19^{*} \\
(0.12)\end{array}$ & $\begin{array}{l}0.29^{*} \\
(0.15)\end{array}$ & $\begin{array}{c}0.01 \\
(0.11)\end{array}$ & $\begin{array}{c}0.02 \\
(0.06)\end{array}$ & $\begin{array}{l}0.72^{* * *} \\
(0.27)\end{array}$ & $\begin{array}{c}0.13 \\
(0.09)\end{array}$ & $\begin{array}{l}-0.05 \\
(0.3)\end{array}$ & $\begin{array}{l}0.32^{*} \\
(0.19)\end{array}$ \\
\hline Equity & $\begin{array}{c}0.02 \\
(0.02)\end{array}$ & $\begin{array}{c}0.05 \\
(0.04)\end{array}$ & $\begin{array}{c}0.01 \\
(0.03)\end{array}$ & $\begin{array}{l}-0.003 \\
(0.02)\end{array}$ & $\begin{array}{l}0.06^{* * *} \\
(0.01)\end{array}$ & $\begin{array}{l}0.005 \\
(0.03)\end{array}$ & $\begin{array}{l}0.08^{* * *} \\
(0.03)\end{array}$ & $\begin{array}{c}0.08 \\
(0.08)\end{array}$ & $\begin{array}{c}-0.006 \\
(0.0358)\end{array}$ \\
\hline Size & $\begin{array}{l}-0.0008 \\
(0.0006)\end{array}$ & $\begin{array}{c}0.0001 \\
(0.0005)\end{array}$ & $\begin{array}{l}-0.0001 \\
(0.0006)\end{array}$ & $\begin{array}{l}-0.0003 \\
(0.0004)\end{array}$ & $\begin{array}{l}0.0006^{* *} \\
(0.0003)\end{array}$ & $\begin{array}{l}-0.0002 \\
(0.0005)\end{array}$ & $\begin{array}{c}0.0009^{*} \\
(0.0005)\end{array}$ & $\begin{array}{l}0.0008 \\
(0.001)\end{array}$ & $\begin{array}{c}-0.0003 \\
(0.0005)\end{array}$ \\
\hline Assets share & $\begin{array}{l}-0.01 \\
(0.02)\end{array}$ & $\begin{array}{l}-0.03 \\
(0.03)\end{array}$ & $\begin{array}{l}0.008 \\
(0.01)\end{array}$ & $\begin{array}{l}-0.002 \\
(0.004)\end{array}$ & $\begin{array}{l}-0.04^{* *} \\
(0.02)\end{array}$ & $\begin{array}{l}0.004 \\
(0.01)\end{array}$ & $\begin{array}{l}-0.003 \\
(0.003)\end{array}$ & $\begin{array}{c}-0.005 \\
(0.02)\end{array}$ & $\begin{array}{c}-0.0002 \\
(0.01)\end{array}$ \\
\hline GDP growth & $\begin{array}{l}-0.16 \\
(0.40)\end{array}$ & $\begin{array}{l}-0.11 \\
(0.08)\end{array}$ & $\begin{array}{c}0.35 \\
(0.68)\end{array}$ & $\begin{array}{l}-0.13 \\
(0.21)\end{array}$ & $\begin{array}{l}-0.05 \\
(0.05)\end{array}$ & $\begin{array}{l}0.06^{*} \\
(0.03)\end{array}$ & $\begin{array}{c}0.03 \\
(0.03)\end{array}$ & $\begin{array}{c}0.01 \\
(0.04)\end{array}$ & $\begin{array}{l}-0.001 \\
(0.02)\end{array}$ \\
\hline Inflation & $\begin{array}{l}-0.13 \\
(0.49)\end{array}$ & $\begin{array}{c}0.02 \\
(0.09)\end{array}$ & $\begin{array}{c}0.49 \\
(0.98)\end{array}$ & $\begin{array}{l}-0.12 \\
(0.22)\end{array}$ & $\begin{array}{l}-0.14 \\
(0.65)\end{array}$ & $\begin{array}{l}0.009 \\
(0.06)\end{array}$ & $\begin{array}{l}-0.04 \\
(0.03)\end{array}$ & $\begin{array}{c}0.01 \\
(0.03)\end{array}$ & $\begin{array}{c}0.002 \\
(0.006)\end{array}$ \\
\hline HHI assets & $\begin{array}{l}-1.31^{*} \\
(0.74)\end{array}$ & $\begin{array}{l}-0.07 \\
(0.05)\end{array}$ & $\begin{array}{c}0.32 \\
(0.49)\end{array}$ & $\begin{array}{l}0.003 \\
(0.05)\end{array}$ & $\begin{array}{l}-0.04 \\
(0.54)\end{array}$ & $\begin{array}{l}0.005 \\
(0.02)\end{array}$ & $\begin{array}{l}-0.002 \\
(0.003)\end{array}$ & $\begin{array}{l}-0.008 \\
(0.01)\end{array}$ & $\begin{array}{l}-0.002 \\
(0.01)\end{array}$ \\
\hline Constant & $\begin{array}{c}0.08 \\
(0.05)\end{array}$ & $\begin{array}{c}0.003 \\
(0.009)\end{array}$ & $\begin{array}{l}-0.04 \\
(0.06)\end{array}$ & $\begin{array}{c}0.01 \\
(0.009)\end{array}$ & $\begin{array}{c}0.002 \\
(0.004)\end{array}$ & $\begin{array}{c}0.004 \\
(0.008)\end{array}$ & $\begin{array}{c}-0.01 \\
(0.009)\end{array}$ & $\begin{array}{l}-0.01 \\
(0.02)\end{array}$ & $\begin{array}{c}0.003 \\
(0.006)\end{array}$ \\
\hline $\begin{array}{l}\text { Observations } \\
\text { Number of banks }\end{array}$ & $\begin{array}{c}1,080 \\
193\end{array}$ & $\begin{array}{l}755 \\
169\end{array}$ & $\begin{array}{c}1,059 \\
185\end{array}$ & $\begin{array}{c}1,031 \\
188\end{array}$ & $\begin{array}{l}854 \\
134\end{array}$ & $\begin{array}{l}842 \\
143\end{array}$ & $\begin{array}{l}778 \\
118\end{array}$ & $\begin{array}{l}660 \\
139\end{array}$ & $\begin{array}{l}750 \\
132\end{array}$ \\
\hline
\end{tabular}

Standard errors appear in parenthesis. Estimations are performed with two-step Arrelano-Bover estimator (system-GMM) with robust standard errors. Year dummies are included. *** $\mathrm{p}<0.01,{ }^{* *} \mathrm{p}<0.05, * \mathrm{p}<0.1$ 
Table 3. The effect of taxes on NIM, depending on size, market power, and market concentration

\begin{tabular}{|c|c|c|c|c|c|c|c|}
\hline & Size & $\begin{array}{l}\text { Market } \\
\text { share } \\
\text { (assets) }\end{array}$ & $\begin{array}{c}\text { Market } \\
\text { share } \\
\text { (loans) }\end{array}$ & $\begin{array}{c}\text { Market } \\
\text { share } \\
\text { (deposits) }\end{array}$ & $\begin{array}{c}\text { HHI } \\
\text { (assets) }\end{array}$ & $\begin{array}{c}\mathrm{HHI} \\
\text { (loans) }\end{array}$ & $\begin{array}{c}\text { HHI } \\
\text { (deposits) }\end{array}$ \\
\hline & 1 & 2 & 3 & 4 & 5 & 6 & 7 \\
\hline NIM $_{t-1}$ & $\begin{array}{c}0.85^{* * *} \\
(0.05)\end{array}$ & $\begin{array}{l}0.85^{* * *} \\
(0.04)\end{array}$ & $\begin{array}{c}0.85^{* * *} \\
(0.05)\end{array}$ & $\begin{array}{l}0.85^{* * *} \\
(0.05)\end{array}$ & $\begin{array}{l}0.83^{* * *} \\
(0.05)\end{array}$ & $\begin{array}{l}0.83^{* * *} \\
(0.05)\end{array}$ & $\begin{array}{l}0.82^{* * *} \\
(0.05)\end{array}$ \\
\hline Tax/profit & $\begin{array}{l}-0.02 \\
(0.01)\end{array}$ & $\begin{array}{c}-0.002 \\
(0.00)\end{array}$ & $\begin{array}{l}-0.003 \\
(0.00)\end{array}$ & $\begin{array}{r}-0.002 \\
(0.00)\end{array}$ & $\begin{array}{c}-0.006 \\
(0.00)\end{array}$ & $\begin{array}{c}-0.007 \\
(0.00)\end{array}$ & $\begin{array}{l}-0.007 \\
(0.00)\end{array}$ \\
\hline Equity & $\begin{array}{l}0.007 \\
(0.02)\end{array}$ & $\begin{array}{l}0.007 \\
(0.02)\end{array}$ & $\begin{array}{l}0.007 \\
(0.02)\end{array}$ & $\begin{array}{l}0.007 \\
(0.02)\end{array}$ & $\begin{array}{c}-0.004 \\
(0.02)\end{array}$ & $\begin{array}{c}-0.003 \\
(0.02)\end{array}$ & $\begin{array}{l}-0.004 \\
(0.02)\end{array}$ \\
\hline Costs & $\begin{array}{l}0.11^{* *} \\
(0.04)\end{array}$ & $\begin{array}{l}0.11^{* *} \\
(0.04)\end{array}$ & $\begin{array}{l}0.11^{* *} \\
(0.04)\end{array}$ & $\begin{array}{l}0.11^{* *} \\
(0.04)\end{array}$ & $\begin{array}{l}0.14^{* * *} \\
(0.05)\end{array}$ & $\begin{array}{l}0.14^{* * *} \\
(0.05)\end{array}$ & $\begin{array}{l}0.14^{* * *} \\
(0.05)\end{array}$ \\
\hline Size & $\begin{array}{c}-0.0006 \\
(0.00)\end{array}$ & $\begin{array}{c}-0.0002 \\
(0.00)\end{array}$ & $\begin{array}{c}-0.0002 \\
(0.00)\end{array}$ & $\begin{array}{c}-0.0002 \\
(0.00)\end{array}$ & $\begin{array}{c}-0.0002 \\
(0.00)\end{array}$ & $\begin{array}{c}0.0002 \\
(0.00)\end{array}$ & $\begin{array}{c}-0.0002 \\
(0.00)\end{array}$ \\
\hline LLP & $\begin{array}{c}0.001^{* *} \\
(0.00)\end{array}$ & $\begin{array}{c}0.001^{* *} \\
(0.00)\end{array}$ & $\begin{array}{c}0.001^{* *} \\
(0.00)\end{array}$ & $\begin{array}{c}0.001^{* *} \\
(0.00)\end{array}$ & $\begin{array}{c}0.001^{* *} \\
(0.00)\end{array}$ & $\begin{array}{c}0.001^{* *} \\
(0.00)\end{array}$ & $\begin{array}{c}0.001^{* *} \\
(0.00)\end{array}$ \\
\hline Assets share & $\begin{array}{c}0.006^{* *} \\
(0.00)\end{array}$ & $\begin{array}{r}-0.005 \\
(0.01)\end{array}$ & $\begin{array}{r}-0.007 \\
(0.01)\end{array}$ & $\begin{array}{r}-0.007 \\
(0.01)\end{array}$ & $\begin{array}{l}0.004^{* *} \\
(0.002)\end{array}$ & $\begin{array}{l}0.006^{* * *} \\
(0.002)\end{array}$ & $\begin{array}{l}0.004^{* *} \\
(0.002)\end{array}$ \\
\hline HHI assets & $\begin{array}{c}-0.004 \\
(0.00)\end{array}$ & $\begin{array}{l}-0.003 \\
(0.00)\end{array}$ & $\begin{array}{c}-0.005 \\
(0.00)\end{array}$ & $\begin{array}{l}-0.003 \\
(0.003)\end{array}$ & $\begin{array}{l}-0.04^{*} \\
(0.02)\end{array}$ & $\begin{array}{l}-0.04^{*} \\
(0.03)\end{array}$ & $\begin{array}{l}-0.04^{*} \\
(0.02)\end{array}$ \\
\hline GDP growth & $\begin{array}{l}0.006 \\
(0.00)\end{array}$ & $\begin{array}{c}0.004 \\
(0.00)\end{array}$ & $\begin{array}{l}0.005 \\
(0.00)\end{array}$ & $\begin{array}{l}0.004 \\
(0.00)\end{array}$ & $\begin{array}{l}0.005 \\
(0.00)\end{array}$ & $\begin{array}{l}0.003 \\
(0.00)\end{array}$ & $\begin{array}{l}0.003 \\
(0.00)\end{array}$ \\
\hline Inflation & $\begin{array}{l}0.006 \\
(0.00)\end{array}$ & $\begin{array}{l}0.006 \\
(0.00)\end{array}$ & $\begin{array}{l}0.007 \\
(0.00)\end{array}$ & $\begin{array}{l}0.006 \\
(0.00)\end{array}$ & $\begin{array}{l}0.007 \\
(0.00)\end{array}$ & $\begin{array}{l}0.008 \\
(0.00)\end{array}$ & $\begin{array}{l}0.008 \\
(0.00)\end{array}$ \\
\hline Tax*size & $\begin{array}{l}0.002 \\
(0.00)\end{array}$ & & & & & & \\
\hline Tax*Share assets & & $\begin{array}{c}0.04 \\
(0.05)\end{array}$ & $\begin{array}{c}0.05 \\
(0.05)\end{array}$ & $\begin{array}{c}0.04 \\
(0.05)\end{array}$ & & & \\
\hline Tax*HHI assets & & & & & $\begin{array}{c}0.14^{*} \\
(0.08)\end{array}$ & $\begin{array}{l}0.16^{*} \\
(0.10)\end{array}$ & $\begin{array}{c}0.14^{*} \\
(0.07)\end{array}$ \\
\hline Constant & $\begin{array}{c}0.006 \\
(0.005)\end{array}$ & $\begin{array}{c}0.001 \\
(0.00)\end{array}$ & $\begin{array}{l}0.002 \\
(0.00)\end{array}$ & $\begin{array}{l}0.002 \\
(0.00)\end{array}$ & $\begin{array}{l}0.004 \\
(0.00)\end{array}$ & $\begin{array}{l}0.004 \\
(0.00)\end{array}$ & $\begin{array}{l}0.004 \\
(0.00)\end{array}$ \\
\hline Observations & 7,938 & 7,938 & 7,934 & 7,937 & 7,938 & 7,934 & 7,937 \\
\hline Number of banks & 1,411 & 1,411 & 1,411 & 1,411 & 1,411 & 1,411 & 1,411 \\
\hline Arrelano-Bond test AR (2) p-value & 0.723 & 0.697 & 0.696 & 0.700 & 0.918 & 0.943 & 0.882 \\
\hline Hansen Test & 0.175 & 0.184 & 0.194 & 0.178 & 0.18 & 0.202 & 0.211 \\
\hline Number of instruments & 35 & 35 & 35 & 35 & 34 & 34 & 34 \\
\hline $\begin{array}{l}\text { Lags for GMM instruments }\left(\mathrm{NIM}_{\mathrm{t}-1}\right) \\
\text { Lags for GMM instruments (other }\end{array}$ & $2-4$ & $2-4$ & $2-4$ & $2-4$ & $3-4$ & 3-4 & 3-4 \\
\hline variables) & 3-4 & 3-4 & 3-4 & 3-4 & 3-4 & 3-4 & 3-4 \\
\hline
\end{tabular}

Standard errors appear in parenthesis. Estimations are performed with two-step Arrelano-Bover estimator (systemGMM) with robust standard errors. Year dummies are included.

*** $\mathrm{p}<0.01, * * \mathrm{p}<0.05, * \mathrm{p}<0.1$ 
Table 4. The impact of taxes on NIM, depending on H-statistics and Lerner index.

\begin{tabular}{|c|c|c|}
\hline & H-stat & Lerner \\
\hline & 1 & 2 \\
\hline \multirow{2}{*}{ NIM $_{t-1}$} & $0.60^{* * *}$ & $0.74^{* * *}$ \\
\hline & $(0.05)$ & $(0.13)$ \\
\hline \multirow[t]{2}{*}{ Tax/profit } & 0.002 & $0.02 *$ \\
\hline & $(0.004)$ & $(0.01)$ \\
\hline \multirow[t]{2}{*}{ Equity } & $0.05^{* * *}$ & $0.13^{* * *}$ \\
\hline & $(0.00)$ & $(0.04)$ \\
\hline \multirow[t]{2}{*}{ Costs } & $0.26^{* * *}$ & 0.03 \\
\hline & $(0.05)$ & $(0.12)$ \\
\hline \multirow[t]{2}{*}{ Size } & $1.54 \mathrm{e}-05$ & $0.001 * *$ \\
\hline & $(0.00)$ & $(0.00)$ \\
\hline \multirow[t]{2}{*}{ LLP } & $0.002^{* * *}$ & 0.0007 \\
\hline & $(0.00)$ & $(0.00)$ \\
\hline \multirow[t]{2}{*}{ Assets share } & $0.004^{*}$ & -0.002 \\
\hline & $(0.00)$ & $(0.00)$ \\
\hline \multirow[t]{2}{*}{ HHI } & $-0.007^{* * *}$ & -0.0004 \\
\hline & $(0.002)$ & $(0.00)$ \\
\hline \multirow{2}{*}{ Lerner } & & 0.00 \\
\hline & & $(0.00)$ \\
\hline \multirow[t]{2}{*}{ GDP growth } & -0.002 & $0.02 *$ \\
\hline & $(0.01)$ & $(0.01)$ \\
\hline \multirow[t]{2}{*}{ Inflation } & $0.02^{* *}$ & 0.001 \\
\hline & $(0.01)$ & $(0.01)$ \\
\hline \multirow[t]{2}{*}{ Tax*H_stat } & -0.001 & \\
\hline & $(0.01)$ & \\
\hline \multirow[t]{2}{*}{ Tax*Lerner } & & -0.0001 \\
\hline & & $(0.00)$ \\
\hline \multirow[t]{2}{*}{ Constant } & 0.001 & $-0.02^{* * *}$ \\
\hline & $(0.00)$ & $(0.00)$ \\
\hline Observations & 7,938 & 4,401 \\
\hline Number of banks & 1,411 & 1,057 \\
\hline Arrelano-Bond test for AR (2) p-value & 0.428 & 0.898 \\
\hline Hansen Test of joint validity of instruments & 0.126 & 0.199 \\
\hline Number of instruments & 33 & 31 \\
\hline Lags for GMM instruments $\left(\mathrm{NIM}_{\mathrm{t}-1}\right)$ & 1,1 & 1,1 \\
\hline Lags for GMM instruments (other variables) & 1,2 & 2,2 \\
\hline
\end{tabular}

Standard errors appear in parenthesis. Estimations are performed with two-step Arrelano-Bover estimator (system-GMM) with robust standard errors. Year dummies are included.

*** $\mathrm{p}<0.01, * * \mathrm{p}<0.05, * \mathrm{p}<0.1$. 
APPENDIX A. VARIABLE DESCRIPTION AND DESCRIPTIVE STATISTICS

Table A. Descriptive statistics for the whole sample (7,938 obs.)

\begin{tabular}{|c|c|c|c|c|c|c|}
\hline Variable & Description & Restrictions & Mean & S.D. & Min & Max \\
\hline NIM & $\begin{array}{l}\text { Bank's net interest revenue less } \\
\text { interest expenses over total assets }\end{array}$ & ]$-0.05 ; 0.11[$ & $2.2 \%$ & $1.3 \%$ & $0.2 \%$ & $6.0 \%$ \\
\hline Fees & $\begin{array}{l}\text { Bank's net fees and commissions } \\
\text { over total assets }\end{array}$ & - & $1.1 \%$ & $1.2 \%$ & $-0.2 \%$ & $11.8 \%$ \\
\hline TAX & $\begin{array}{l}\text { Bank’s taxes } \\
\text { over pre-tax profit }\end{array}$ & ] $0 ; 1[$ & $31.2 \%$ & $14.7 \%$ & $0.1 \%$ & $98.8 \%$ \\
\hline Assets & $\begin{array}{l}\text { Bank's total assets } \\
\text { (in thousand euros) }\end{array}$ & - & 25,182 & 104,918 & 11 & $2,150,536$ \\
\hline Deposits & $\begin{array}{l}\text { Bank's deposits } \\
\text { over total assets }\end{array}$ & - & $78.6 \%$ & $13.9 \%$ & $0.0 \%$ & $98.2 \%$ \\
\hline Equity & $\begin{array}{l}\text { Bank's equity } \\
\text { over total assets }\end{array}$ & ] $0 ; 1[$ & $8.0 \%$ & $4.8 \%$ & $1.3 \%$ & $29.9 \%$ \\
\hline Cost & $\begin{array}{l}\text { Bank's non-interest expenses } \\
\text { over total assets }\end{array}$ & ]0; 0.2[ & $1.2 \%$ & $0.8 \%$ & $0.1 \%$ & $4.0 \%$ \\
\hline Loan Loss Prov. & $\begin{array}{l}\text { Bank’s loan loss provisions } \\
\text { over total assets }\end{array}$ & ]$-0.25 ; 1[$ & $12.7 \%$ & $15.1 \%$ & $-25.0 \%$ & $100.0 \%$ \\
\hline ROE & $\begin{array}{l}\text { Bank's pre-tax profit } \\
\text { over total assets }\end{array}$ & $>0$ & $11.0 \%$ & $17.5 \%$ & $0.0 \%$ & $700.9 \%$ \\
\hline ROA & $\begin{array}{l}\text { Bank's pre-tax profit } \\
\text { over total assets }\end{array}$ & $>0$ & $0.8 \%$ & $0.7 \%$ & $0.0 \%$ & $10.0 \%$ \\
\hline Market share ${ }^{\text {a) }}$ & $\begin{array}{l}\text { Bank's total assets as a share of } \\
\text { banks' total assets in a country } \\
\text { (within the sample) }\end{array}$ & - & $1.3 \%$ & $4.2 \%$ & $0.0 \%$ & $70.9 \%$ \\
\hline HH Index a) & $\begin{array}{l}\text { Herfindhal-Hirschman index of } \\
\text { banking market concentration }\end{array}$ & - & $9.3 \%$ & $7.2 \%$ & $2.6 \%$ & $52.3 \%$ \\
\hline Lerner Index a) & Bank’s market power & - & $25.6 \%$ & $13.4 \%$ & $-51.7 \%$ & $81.6 \%$ \\
\hline h-stat ${ }^{\text {a) }}$ & $\begin{array}{l}\text { Panzar and Rosse (1987)'s index } \\
\text { of banking market competition }\end{array}$ & - & $63.0 \%$ & $15.9 \%$ & $35.9 \%$ & $89.5 \%$ \\
\hline GDP & $\begin{array}{l}\text { Gross Domestic Product } \\
\text { growth rate }\end{array}$ & - & $2.5 \%$ & $22.9 \%$ & $-2.3 \%$ & $11.3 \%$ \\
\hline CPI & $\begin{array}{l}\text { Rate of Consumer Price Index } \\
\text { inflation }\end{array}$ & - & $2.1 \%$ & $1.2 \%$ & $-13.8 \%$ & $20.6 \%$ \\
\hline
\end{tabular}

Source: Banskope. ${ }^{\text {a) }}$ Authors' calculations. For variable that divide a flow variable on a stock variable, we construct the denominators as the mean of the variable between $t$ and $t-1$. 


\section{Table B. Number of observations and mean values by country of residence}

This table provides a breakdown of our sample of banks by the country of location. See Table A for the definition of the variables.

\begin{tabular}{|c|c|c|c|c|c|c|c|c|c|c|c|c|c|c|c|c|c|}
\hline & $\begin{array}{l}\text { Nb. of } \\
\text { Obs. }\end{array}$ & NIM & Fees & Tax & $\begin{array}{c}\text { Assets } \\
\text { (th. euros) }\end{array}$ & Deposits & Equity & Cost & $\begin{array}{l}\text { Loan } \\
\text { Loss } \\
\text { Prov. }\end{array}$ & ROE & ROA & $\begin{array}{c}\text { Market } \\
\text { share }\end{array}$ & $\begin{array}{c}\text { HH } \\
\text { Index }\end{array}$ & $\begin{array}{l}\text { Lerner } \\
\text { Index }\end{array}$ & h-stat & GDP & CPI \\
\hline AT & 257 & $1.9 \%$ & $1.4 \%$ & $24 \%$ & 10,351 & $7.6 \%$ & $79 \%$ & $1.3 \%$ & $15 \%$ & $12.3 \%$ & $0.9 \%$ & $1.3 \%$ & $9.1 \%$ & $24.5 \%$ & $72.3 \%$ & $2.3 \%$ & $2.0 \%$ \\
\hline BE & 210 & $1.6 \%$ & $0.9 \%$ & $31 \%$ & 50,492 & $5.1 \%$ & $87 \%$ & $1.0 \%$ & $8 \%$ & $20.9 \%$ & $0.6 \%$ & $2.5 \%$ & $11.6 \%$ & $18.1 \%$ & $89.5 \%$ & $2.3 \%$ & $2.0 \%$ \\
\hline CH & 1,033 & $1.6 \%$ & $1.6 \%$ & $24 \%$ & 16,821 & $10.3 \%$ & $73 \%$ & $1.2 \%$ & $14 \%$ & $16.8 \%$ & $0.9 \%$ & $0.6 \%$ & $21.1 \%$ & $18.5 \%$ & $45.0 \%$ & $1.8 \%$ & $1.0 \%$ \\
\hline DE & 793 & $2.0 \%$ & $1.1 \%$ & $34 \%$ & 26,262 & $7.2 \%$ & $83 \%$ & $1.2 \%$ & $18 \%$ & $11.9 \%$ & $0.7 \%$ & $0.4 \%$ & $4.0 \%$ & $27.1 \%$ & $61.2 \%$ & $1.6 \%$ & $1.6 \%$ \\
\hline DK & 510 & $3.7 \%$ & $1.1 \%$ & $26 \%$ & 8,098 & $11.0 \%$ & $80 \%$ & $1.9 \%$ & $10 \%$ & $11.4 \%$ & $1.3 \%$ & $1.3 \%$ & $16.1 \%$ & $34.4 \%$ & $35.9 \%$ & $1.6 \%$ & $2.1 \%$ \\
\hline ES & 573 & $2.5 \%$ & $1.0 \%$ & $30 \%$ & 28,135 & $8.5 \%$ & $83 \%$ & $1.3 \%$ & $14 \%$ & $12.6 \%$ & $1.0 \%$ & $1.4 \%$ & $8.4 \%$ & $29.7 \%$ & $67.0 \%$ & $2.1 \%$ & $3.2 \%$ \\
\hline FI & 43 & $1.4 \%$ & $0.6 \%$ & $23 \%$ & 41,391 & $6.0 \%$ & $68 \%$ & $0.7 \%$ & $6 \%$ & $12.1 \%$ & $0.8 \%$ & $14.9 \%$ & $30.5 \%$ & $23.3 \%$ & $82.0 \%$ & $3.5 \%$ & $1.7 \%$ \\
\hline FR & 1,090 & $2.6 \%$ & $1.2 \%$ & $33 \%$ & 30,450 & $7.2 \%$ & $80 \%$ & $1.5 \%$ & $13 \%$ & $11.1 \%$ & $0.8 \%$ & $0.4 \%$ & $5.2 \%$ & $20.5 \%$ & $81.8 \%$ & $3.8 \%$ & $1.7 \%$ \\
\hline GB & 683 & $2.2 \%$ & $1.0 \%$ & $30 \%$ & 63,941 & $9.1 \%$ & $80 \%$ & $1.1 \%$ & $9 \%$ & $10.9 \%$ & $0.9 \%$ & $0.8 \%$ & $4.4 \%$ & $27.3 \%$ & $52.6 \%$ & $2.1 \%$ & $2.9 \%$ \\
\hline GR & 115 & $2.9 \%$ & $1.3 \%$ & $31 \%$ & 19,512 & $8.3 \%$ & $83 \%$ & $1.6 \%$ & $18 \%$ & $12.7 \%$ & $1.1 \%$ & $9.3 \%$ & $16.7 \%$ & $21.7 \%$ & $87.7 \%$ & $2.8 \%$ & $4.2 \%$ \\
\hline IE & 97 & $1.9 \%$ & $0.6 \%$ & $22 \%$ & 38,608 & $6.0 \%$ & $79 \%$ & $0.8 \%$ & $10 \%$ & $13.4 \%$ & $0.8 \%$ & $7.3 \%$ & $11.8 \%$ & $28.6 \%$ & $74.6 \%$ & $3.8 \%$ & $3.3 \%$ \\
\hline IT & 1,074 & $2.8 \%$ & $1.3 \%$ & $45 \%$ & 18,059 & $8.1 \%$ & $68 \%$ & $1.6 \%$ & $15 \%$ & $9.1 \%$ & $0.7 \%$ & $0.7 \%$ & $5.4 \%$ & $26.5 \%$ & $53.9 \%$ & $6.7 \%$ & $2.6 \%$ \\
\hline LU & 854 & $0.8 \%$ & $0.9 \%$ & $33 \%$ & 5,923 & $4.9 \%$ & $87 \%$ & $0.6 \%$ & $9 \%$ & $72.1 \%$ & $0.6 \%$ & $1.1 \%$ & $3.6 \%$ & $18.2 \%$ & $83.6 \%$ & $1.4 \%$ & $2.0 \%$ \\
\hline NL & 214 & $1.5 \%$ & $0.6 \%$ & $26 \%$ & 51,870 & $6.7 \%$ & $76 \%$ & $0.8 \%$ & $10 \%$ & $9.2 \%$ & $0.7 \%$ & $2.6 \%$ & $19.5 \%$ & $19.7 \%$ & $54.6 \%$ & $4.4 \%$ & $2.1 \%$ \\
\hline NO & 100 & $2.3 \%$ & $0.4 \%$ & $23 \%$ & 13,322 & $7.2 \%$ & $75 \%$ & $0.9 \%$ & $5 \%$ & $9.4 \%$ & $0.9 \%$ & $5.9 \%$ & $14.9 \%$ & $14.5 \%$ & $46.9 \%$ & $2.8 \%$ & $2.0 \%$ \\
\hline PT & 163 & $2.2 \%$ & $0.7 \%$ & $19 \%$ & 13,062 & $7.6 \%$ & $80 \%$ & $1.2 \%$ & $18 \%$ & $9.2 \%$ & $0.8 \%$ & $3.9 \%$ & $9.0 \%$ & $21.4 \%$ & $81.6 \%$ & $3.4 \%$ & $3.1 \%$ \\
\hline SE & 129 & $2.4 \%$ & $1.1 \%$ & $26 \%$ & 35,099 & $8.7 \%$ & $76 \%$ & $1.2 \%$ & $6 \%$ & $10.9 \%$ & $0.9 \%$ & $5.0 \%$ & $16.7 \%$ & $31.3 \%$ & $50.3 \%$ & $3.4 \%$ & $1.5 \%$ \\
\hline Total & 7,938 & $2 \%$ & $1.1 \%$ & $31 \%$ & 25,182 & $8.0 \%$ & $79 \%$ & $1.2 \%$ & $13 \%$ & $18.5 \%$ & $0.8 \%$ & $1.3 \%$ & $9.3 \%$ & $23.9 \%$ & $63.0 \%$ & $2.7 \%$ & $2.1 \%$ \\
\hline
\end{tabular}

Source: Banskope. Authors’ calculation. 


\section{LIST OF WORKING PAPERS RELEASED BY CEPII}

An exhaustive list is available on the website: Ilwww.cepii.fr.

No

Title

2013-08 Internationalization Versus Regionalization in the Emerging Stock Markets

2013-07 Economic Policy, Tourism Trade and Productive Diversification

2013-06 Product Standards and Margins of Trade: Firm Level Evidence

2013-05 If Foreign Investment is not Foreign: Round-Trip Versus Genuine Foreign Investment in Russia

2013-04 Preferential Trade Agreements Proliferation: Sorting out the Effects

2013-03 Trend Shocks and Economic Development

2013-02 Nonlinearity of the Inflation-output Trade-off and Time-Varying Price Rigidity

2013-01 The Solow Growth Model with Keynesian Involuntary Unemployments

2012-38 Does Migration Foster Exports? An African Perspective"

2012-37 The ECB Unconventional Monetary Policies: Have they Lowered Market Borrowing Costs for Banks and Governments?

2012-36 The Impact of Market Regulations on Intra-European Real Exchange Rages
Authors

V. Coudert, K. Hervé, \&

P. Mabille

I. Lejárraga \& P. Walkenhorst

L. Fontagné, G. Orefice, R. Piermartini \& N.Rocha

S. Ledyaeva, P. Karhunen \& J. Walley

S. Bensassi, J. de Sousa \& J. Jarreau

C. F. Naoussi \& F. Tripier

A. López-Villavicencio \& V. Mignon

R. Magnani

H. Ehrhart, M. Le Goff, E. Rocher \& R. J. Singh

U. Szczerbowicz

A. Bénassy-Quéré \& D. Coulibaly 
2012-35 Exchange Rate volatility, Financial Constraints and Trade: Empirical Evidence from Chinese Firms

2012-34 Multinational Retailers and Home Country Exports

2012-33 Food Prices and Inflation Targeting in Emerging Economies

2012-32 Fiscal Consolidations and Banking Stability

2012-31 The Contribution of the Yen Appreciation since 2007 to the Japanese Economic Debacle

2012-30 Are the Benefits of Exports Support Durable?

2012-29 Les dessous de la dette publique japonaise

2012-28 Invoicing Currency, Firm Size, and Hedging

2012-27 Product Relatedness and Firm Exports in China

2012-26 Export Upgrading and Growth: the Prerequisite of Domestic Embeddedness

2012-25 Time to Ship During Financial Crises

2012-24 Foreign Ownership Wage Premium: Does financial Health Matter?

2012-23 Tax Reform and Coordination in a Currency Union

2012-22 The Unequal Effects of Financial Development on Firms' Growth in India
J. Héricourt \& S. Poncet

A. Cheptea, C. Emlinger \& K. Latouche

M. Pourroy, B. Carton \& D. Coulibaly

J. Cimadomo, S. Hauptmeier \& T. Zimmermann

W. Thorbecke

$$
\text { O. Cadot, }
$$
A. M. Fernandes, J. Gourdon \& A. Mattoo

E. Dourille-Feer J. Martin \& I. Méjean

S. Poncet \& F. Starosta de Waldemar

S. Poncet \& F. Starosta de Waldemar

N. Berman, J. de Sousa P. Martin \& T. Mayer

M. Bas

B. Carton

M. Bas \& A. Berthou 
2012-21 Pegging Emerging Currencies in the Face of Dollar Swings

2012-20 On the Links between Stock and Comodity Markets' Volatility

2012-19 European Export Performance, Angela Cheptea

2012-18 The Few Leading the Many: Foreign Affiliates and Business Cycle Comovement

2012-17 Native Language, Spoken Language, Translation and Trade

2012-16 Assessing the Price-Raising Effect of Non-Tariff Measures in Africa

2012-15 International Migration and Trade Agreements: the New Role of PTAs

2012-14 Scanning the Ups and Downs of China's Trade Imbalances

2012-13 Revisiting the Theory of Optimum Currency Areas: Is the CFA Franc Zone Sustainable?

2012-12 Macroeconomic Transmission of Eurozone Shocks to Emerging Economies

2012-11 The fiscal Impact of Immigration in France: a Generational Accounting Approach

2012-10 MAcMap-HS6 2007, an Exhaustive and Consistent Measure of Applied Protection in 2007

2012-09 Regional Integration and Natural Resources: Who Benefits? Evidence from MENA
V. Coudert, C. Couharde \& V. Mignon

A. Creti, M. Joëts \& V. Mignon

A. Cheptea, L. Fontagné \& S. Zignago

J. Kleinert, J. Martin \& F. Toubal

J. Melitz \& F. Toubal O.Cadot \& J.Gourdon

G. Orefice

F. Lemoine \& D. Ünal

C. Couharde,

I. Coulibaly, D. Guerreiro \& V. Mignon

B. Erten

X. Chojnicki

H. Guimbard, S. Jean, M. Mimouni \& X. Pichot

C. Carrère, J. Gourdon \& M. Olarreaga 
No

Title

Authors

2012-08 A Foreign Direct Investment Database for Global CGE Models

C. Gouël, H. Guimbard \& D. Laborde

2012-07 On Currency Misalignments within the Euro Area

V. Coudert, C. Couharde \& V. Mignon

2012-06 How Frequently Firms Export? Evidence from France

G. Békés, L. Fontagné, B. Muraközy \& V. Vicard

2012-05 Fiscal Sustainability in the Presence of Systemic Banks: the Case of EU Countries

A. Bénassy-Quéré \& G. Roussellet

2012-04 Low-Wage Countries' Competition, Reallocation across Firms and the Quality Content of Exports

J. Martin \& I. Méjean

2012-03 The Great Shift: Macroeconomic Projections for the World Economy at the 2050 Horizon

J. Fouré, A. Bénassy-Quéré \& L. Fontagné

2012-02 The Discriminatory Effect of Domestic Regulations on International Services Trade: Evidence from FirmLevel Data

M. Crozet, E. Milet \& D. Mirza

2012-01 Optimal food price stabilization in a small open developing country

C. Gouël \& S. Jean 
Organisme public d'étude et de recherche en économie internationale, le CEPII est placé auprès du Centre d'Analyse Stratégique. Son programme de travail est fixé par un conseil composé de responsables de l'administration et de personnalités issues des entreprises, des organisations syndicales et de l’Université.

Les documents de travail du CEPII mettent à disposition du public professionnel des travaux effectués au CEPII, dans leur phase d'élaboration et de discussion avant publication définitive. Les documents de travail sont publiés sous la responsabilité de la direction du CEPII et n'engagent ni le conseil du Centre, ni le Centre d'Analyse Stratégique. Les opinions qui y sont exprimées sont celles des auteurs.

Les documents de travail du CEPII sont disponibles sur le site : http//www.cepii.fr. 